\title{
DR. VIKTOR RUŽIĆ (1893.-1976.) KAO SUDIONIK DRŽAVNOPRAVNIH ZBIVANJA
}

Prof. dr. sc. Željko Bartulović*

\author{
UDK 34-05Ružić, V. \\ https://doi.org/10.30925/zpfsr.39.2.8 \\ Ur.: 30. listopada 2017. \\ Pr.: 20. travnja 2018. \\ Prethodno priopćenje
}

\begin{abstract}
Sažetak
Dr. Viktor Ružić član je ugledne riječke/sušačke hrvatske obitelji čiji su članovi pobornici pravaštva. Temelj istraživanja je Ružićev tekst „Moje uspomene“ nastao 1968. koji doprinosi stvaranju slike o njegovoj osobi i političkim događajima u kojima je uzeo učešća. Njegovu mladost obilježava borba protiv mađarizacije, dolazak Frana Supila, Riječka deklaracija 1905. i nastanak Hrvatsko-srpske koalicije. U politiku se uključuje 1918. ulazeći u narodno vijeće Slovenaca, Hrvata i Srba. Tijekom talijanske okupacije Rijeke i Sušaka (1918.1923./1924.) upozorava na postupke iredentista te probleme pri uspostavi vlasti Kraljevstva SHS, osobito na uvođenje oblasti što je izazivalo sukobe između hrvatskih političara i centralističkog režima u Beogradu. Važni su podatci o izborima u Sušaku tijekom dvadesetih godina 20. stoljeća. Politički zenit dr. Ružić doživljava tridesetih godina 20. stoljeća kada je obnašao dužnost bana Banovine Savske i ministra pravde u vladi dr. Milana Stojadinovića. Nakon vojnog poraza Kraljevine Jugoslavije 1941., tijekom talijanske okupacijel aneksije dr. Ružić je interniran u Italiji, a u doba njemačke vojne uprave od 1943. do 1945. sa skupinom građanskih političara pomaže stanovništvu, ali se ne pridružuje antifašističkom pokretu na čelu s komunistima. Zato su 1945. protivnici višsestranačkog sustava i pluralizma mišljenja ,,montiranim “ sudskim postupkom isključiti dr. Ružića iz javnog života.
\end{abstract}

Ključne riječi: Viktor Ružić, Sušak/Rijeka, Hrvatska, povijest države, 20. stoljeće.

\section{UVOD}

Doktor Viktor Ružić, član ugledne hrvatske obitelji iz Rijeke/Sušaka, gospodarstvenik, pravnik, političar, značajna osoba predratnoga grada Sušaka. Kako nije pristao uz komuniste osuđen je u namještenom suđenju 1945. što je značilo i osudu „,na šutnju“ do 1990. godine. ${ }^{1}$ Zbog toga su bitna njegova sjećanja u donedavno

* Dr. sc. Željko Bartulović, redoviti profesor Sveučilišta u Rijeci, Pravnog fakulteta; zeljko@ pravri.hr. 
neobjavljenim Mojim uspomenama koje je počeo pisati 22. veljače $1968 .{ }^{2}$ Nevelik rukopis, 55 stranica pisanih strojem, uz podatke osobne naravi, sadrži i one o državnopravnim zbivanjima, kao i ocjene događaja na Sušaku i šire.

Rukopis se može podijeliti na četiri cjeline. Prva (str. 1-9), obuhvaća mladalačke dane do Prvog svjetskog rata kada se uključuje u politiku. Druga, međuratno razdoblje, u kojoj opisuje svoj politički rad (str. 9-36), može se podijeliti na dio koji većinom opisuje zbivanja u svezi s Rijekom (str. 9-20) i sudjelovanje u politici na razini države (str. 21-36). Treća (str. 37-48), sadrži zapise o Drugom svjetskom ratu, internaciji u Italiji i povratku na Sušak, a četvrta (str. 48-55) događanja i Ružićevu sudbinu nakon rata, smrti supruge 1964. godine. Sjećanja su, osim nekoliko detalja, pisana kronološki pa će se metodološki analizirati i objašnjavati pojedini zapisi spram državnopravnih događanja i osoba na koje se odnose. Dio istraživanja temelji se na zapisnicima saslušanja dr. Ružića sastavljenim po OZN-i za Hrvatsko primorje od 19. do 24. srpnja 1945. i njihovoj usporedbi sa sjećanjima. ${ }^{3}$

Pravni fakultet Sveučilišta u Rijeci dobio je od obitelji dio knjižnog fonda, većinom pravne naslove, iz ostavštine dr. Viktora Ružića koji su bibliografski obrađeni, no predstoji rad na digitalizaciji. ${ }^{4}$ Ovaj rad ujedno je prilog istraživanju državne i pravne povijesti Rijeke i značajnih pravnika u 45. obljetnici postojanja pravnog studija u Rijeci.

\section{OBITELJ I MLADOST DR. VIKTORA RUŽIĆA}

Otac Viktora Ružića, Gjuro Ružić stariji, (Hreljin, 1834. - Sušak, 1922.) bio je jedan od najuglednijih Hrvata Rijeke, trgovac kožom, tvorničar, veleposjednik, suosnivač hrvatskoga parobrodarskog društva Società Ungaro Croata (od 1918. Jadranska plovidba d.d.) i Banke $i$ štedionice za Primorje, jedan od čelnika Narodne čitaonice Riečke, načelnik Sušaka, a koji je u politici podržavao pravaše. Majka, Jelka Badovinac (1861.-1928.), druga supruga Gjure st., bila je kći Nikole Badovinca, gradonačelnika Zagreba (1885.-1887.). ${ }^{5}$ Gjurin brat Ivan (1849.-1915.) studirao je pravo u Parizu, Heidelbergu, Berlinu i Beču gdje je doktorirao. Bio je odvjetnik na

1 Tako ga ne spominje Andrassy, iako piše o njegovom ocu Đuri st. i stricu Ivanu. Andrassy, J., Marijan Derenčin, Ivan Ružić, Milan Rojc, Zagreb, Odvjetnik, Glasilo Advokatske komore u SRH, 9/1968, str. 174-183. Isto, niti Rošić, Đ., O hrvatskim i riječkim advokatima u doba Provizorijuma i do anektiranja Rijeke Italiji, Zagreb, Odvjetnik, Glasilo Advokatske komore u SRH, 9/1968, str. 190-197.

2 Ružić, V., Moje uspomene, Rijeka, Udruga štovatelja Spomeničke knjižnice i zbirke MažuranićBrlić-Ružić, 2013. Autor je za pisanje rada koristio presliku i numeracije izvornika dobivenog od Gilde i Matilde Ružić.

3 Život koji teče, Monografija o dr. Viktoru Ružiću (prir. Vujić, V.), Rijeka, Zaklada „Dr. Viktor Ružić“ i Rotary Club Rijeka, 2018, str. 159-195.

4 Golenko, D., Digitalna bibliografska zbirka knjiga dr. Viktora Ružića na Pravnom fakultetu Sveučilišta u Rijeci u: Život koji teče, str. 309-313.

5 Müller-Thomamuhl, D., Moj djed Đuro Ružić, Rijeka, Sušačka revija, god. II, 8/1994, str. 8990. Rački, A., Povijest grada Sušaka, (reprint), Rijeka, Skupština općine Rijeka i Izdavački centar Rijeka, 1990, str. 53-54 smatra Gjuru Ružića “ocem modernoga Sušaka”. 
Sušaku, starčevićanac, zastupnik u Saboru 1894.-1897. i pravni pisac. ${ }^{6}$ Stariji brat dr. Viktora Ružića, Gjuro (Đuro, Jurica) ml. (1891.-1976.), završio je ekonomske studije u Londonu. Bio je gradski načelnik Sušaka od 1930. do 1938. godine. ${ }^{7}$

Prvo ,političko“ sjećanje seže u 1899. kada se nasipavala obala na Brajdici, a djeca su ,plakali i priklinjali Madžare, da nam oduzimlju more. "8 Općina Sušak uređivala je otvorena skladišta na Brajdici, dok je Ugarska osporavala pravo na taj dio obale. Kako bi se spriječile poplave 1854./1855. prokopan je novi, istočniji tok Rječine, a staro korito nazvano je Mrtvi kanal. Tako je nastao međuprostor Delte. Nakon sklapanja Hrvatsko-ugarske nagodbe 1868. i izostankom sporazuma o Rijeci, ustanovljen je privremeni riječki ,, corpus separatum “kojim su Mađari upravljali putem zajedničkih tijela vlasti u kojima su imali prevlast (zajednički Ugarsko-hrvatski sabor i vlada te guverner kojeg je na prijedlog predsjednika vlade, bez ikakvoga hrvatskog utjecaja, imenovao vladar). Mađari su tvrdili da je granica ,, corpus separatuma “ novo korito Rječine, dok je hrvatska strana ukazivala da $\S 66$. Nagodbe određuje staro korito kao granicu. Spor podsjeća na suvremeni granični prijepor između Hrvatske i Slovenije u slučaju rijeke Dragonje. Ugarska je gradila luku Baroš od 1890. do 1894. na prostoru koji je bio privatno vlasništvo ugarske vlade, ali je upravno bio dio Općine Sušak i Hrvatske. Mađari ostvaruju vlast nad lukom i obalom putem Pomorske uprave u Rijeci, pod zajedničkom vladom u Pešti.

Ružić piše da je 1899. Nikola Pašić, srbijanski političar i čelnik Radikalne stranke, koji je zbog neslaganja s kraljem Aleksandrom Obrenovićem izbjegao u Austro-Ugarsku, u Opatiju, za ljetni odmor iznajmio dio vile Ružićevih u Fužinama. ${ }^{9}$ Ovo potvrđuje ugled obitelji i stvaranje poznanstava koji su utjecali na buduću političku karijeru dr. Ružića.

Hrvatska je tijekom banovanja mađarona Karolya Khuena Hedervarya (1883.1903.), proživljavala doba snažne mađarizacije što je dovodilo do političkih otpora. Kulminacija je uslijedila 1903. kada Ugarsko-hrvatski sabor odbija hrvatske zahtjeve za izmjenama financijskih odredbi Nagodbe pa dolazi do prosvjeda koji su donijeli i žrtve, npr. u Zaprešiću. Manje je poznato da je i na Sušaku došlo do većih nemira u svibnju 1903., pa je 22. svibnja ban uveo prijeki sud za kotare Sušak i Delnice te grad

6 Žic, I., Dr. Ivan Ružić, Rijeka, Sušačka revija, god. I, 2-3/1993., str. 29-30; Andrassy, Marijan Derenčin, str. 177. Bio je jedan od odvjetnika u procesu protiv đaka koji su spalili mađarsku trobojku u Zagrebu 1895. Horvat, J., Politička povijest Hrvatske, I. dio, II. izd., Zagreb, August Cesarec, 1990, str. 234.

7 Lukežić, I., Nebo nad Kvarnerom, Rijeka, Izdavački centar Rijeka, 2005, str. 60-61; id., Tvorci modernog Sušaka, Rijeka, Sušačka revija, god. II, 5/1994, str. 14-15.

8 Ružić, Moje uspomene, str. 2. Vidi i Bartulović, Ž., Sušak 1919.-1947, Državnopravni položaj grada, Rijeka, Pravni fakultet Sveučilišta u Rijeci, Državni arhiv u Rijeci i Adamić d.o.o., 2004, str. 25, 34-35.

9 Moje uspomene, str. 2. Nikola Pašić optužen nakon „Ivanjdanskog atentata“ na bivšeg kralja Milana Obrenovića 1899., bio je osuđen pa pomilovan. Austro-Ugarska se plašila da će osuda radikala dovesti do miješanja Rusije u Srbiju koja je za vladavine Obrenovića, osobito sporazumom iz 1897. bila pod jačim utjecajem Beča sve do tzv. „Majskog prevrata“ 1903. kada su zbačeni Obrenovići, a na prijestolje dolaze Karađorđevići koji vode prorusku politiku. Bartulović, Ž. i Ranđelović, N., Osnovi ustavne istorije jugoslovenskih naroda, Niš, Pravni fakultet Univerziteta u Nišu, 2012, str. 84-85. 
Bakar. To je u Hrvatskoj uvedeno još samo u kotarima Križevci i Ludbreg. Uhićenici su „trpani u željezničke vagone za marvu“ i upućivani u istražni zatvor u Ogulinu i Gospiću. ${ }^{10}$ Dr. Ružić se kao dijete sjećao političkih zatočenika koji su u stočnim vagonima prevoženi u Ogulin na suđenje i skupa protiv režima u Bakru na kojem su govorili pravaši, zastupnik Bakra u Hrvatskom saboru Erazmo Barčić i bakranin Cezar Akačić, kasniji saborski zastupnik. Bila je to javna pučka skupština održana 22. studenog 1903. ispred Narodnog doma u nazočnosti oko 3.500 ljudi.. ${ }^{11}$

Odlazak Khuena Hedervarya 1903. dovodi do obrata na hrvatskoj političkoj sceni kojeg su potaknuli političari iz Dalmacije zalažući se za suradnju s mađarskom oporbom koja je tražila osamostaljenje od Austrije. Zauzvrat, Mađari bi podržali utjelovljenje Dalmacije Hrvatskoj i Slavoniji. Dolazi do sastanka s mađarskom opozicijom u rujnu 1905. u Opatiji, a 2.-3. listopada u Rijeci je potpisana Riječka rezolucija koju su sastavili dr. Ante Trumbić iz Dalmacije i Fran Supilo. Uslijedila je Zadarska rezolucija 17. listopada 1905. kada su se programu pridružili politički predstavnici Srba u Dalmaciji i Hrvatskoj. Nastaje Hrvatsko-srpska koalicija koja uz suradnju Hrvata i Srba uvodi protuaustrijski i projugoslavenski program. Vodeću riječ u njoj s hrvatske strane imao je dio pravaša okupljen u Hrvatskoj stranci prava, dok je protiv bila Čista/Starčevićeva stranka prava Josipa Franka. ${ }^{12}$

Gjuro Ružić bio je jedan od pokretača sušačkog lista Hrvatska sloga, koji je 1898. trebao nastaviti tradicije pravaške Slobode, ali bez većeg uspjeha pa je pozvan Fran Supilo, pravaški političar, novinar i publicista, koji od 1900. izdaje Novi list. O osobnim i političkim vezama svjedoči dr. Viktor Ružić. Na Učki je 1912. nastala fotografija s njim, a Ružiću se usjekla u sjećanje njegova znakovita primjedba: , Sada bjesni balkanski rat - doći će kasnije do propasti Austrije, stvoriti će se Jugoslavija, no ako iz nje ne izbacimo Pribićevića, nikad mira u njoj. "13 Komentar izražava politički sukob između Supila koji je napustio vodstvo Hrvatsko-srpske koalicije, a naslijedio ga je Svetozar Pribićević. Supilo zamjera Koaliciji gubitak borbenosti protiv mađarskih presizanja. Očito je nepovjerenje spram Pribićevićevih odnosa prema Beogradu i mogućoj štetnosti za ideju jugoslavenstva i hrvatske interese. ${ }^{14}$

Ružić je pod utjecajem Supila prihvatio mišljenje da političku borbu za hrvatske interese treba voditi protiv Beča koji diktira politička kretanja u Monarhiji, suradnjom s oporbom u Ugarskoj i Srbima u Hrvatskoj. Ističe da sukob između Hrvata i Srba odgovara austrijskim političkim krugovima, navodeći riječi prof. Bernatzika s

10 Kovačić, I., Branili su Hrvatsku, Rijeka, Adamić, 1997, str. 107-114 i 258.

11 Ružić, Moje uspomene, str. 3. Kovačić, Branili su, str. 302-306. Khuenov režim završio je nakon krvavih prosvjeda. Bartulović, Ž., Povijest hrvatskog prava i države (kompendij za internu uporabu), Rijeka, 2008./2009., str. 54. O Barčiću vidi Gross, M., Erazmo Barčić, Zagreb, Odvjetnik, Glasilo Advokatske komore u SRH, 9/1968, str. 198-205.

12 Bartulović, Povijest, str. 55-56 i 58.

13 Ružić, Moje uspomene, str. 6; Lukežić, Nebo, str. 201 i 229-230; id., Gjuro Ružić stariji i Šime Mazzura, u: Život koji teče, str. 48-49.

14 Bartulović i Ranđelović, Osnovi, str. 134. O odnosu Supila spram Hrvatsko-srpske koalicije vidi i Bartulović, Ž. i Papić, V., Stjepan Radić i HPSS u riječkom "Novom listu” do 1914 i H(R)SS u Hrvatskom primorju 1920-1940. u: Zbornik radova "110 godina Hrvatske seljačke stranke", Zagreb, Matica hrvatska, Povijesno društvo Križevci i Zaklada braće Radić, 2015, str. 323-346. Supilo, F., Politički spisi, ur. Šepić D., Zagreb, Znanje, 1970, str. 50-54. 
Pravnog fakulteta u Beču koji je predavanje, spominjući to pitanje, zaključio: ,Dakle, gospodo, tako možemo mirno spavati." Ružić, ipak ne gubi osjećaj pripadnosti hrvatskom korpusu pa u sljedećem pasusu piše da se prebacio na studij u Zagreb jer je osjetio da mu nedostaje ,, hrvatska termina tehnika“ ". ${ }^{15}$

Dr. Ružić je 1913. pristupio Jugoslavenskoj nacionalnoj omladini, političkoj organizaciji jugoslavenskog usmjerenja. Opisuje skupove podrške crnogorskom osvajanju Skadra u Prvom balkanskom ratu 1912./1913. i suprotstavljanje pravašima. ${ }^{16}$ To su „frankovci“, članovi, tzv. Čiste/Starčevićeve stranke prava, jer su se Folnegovićevi pravaši „domovinaši“ i „milinovci“ Mile Starčevića priklonili jugoslavenskoj ideji. ${ }^{17}$ Ružić je zbog , opće tjelesne slabosti “ proglašen nesposobnim za vojsku pa je odlaskom u vojsku braće Jurice i Zvonimira od 1914. vodio poslove obiteljske tvrtke te istodobno studirao pravo u Grazu i Zagrebu. ${ }^{18}$

\section{PROPAST AUSTRO-UGARSKE, NARODNO VIJEĆE SHS I RIJEKA DO 1924.}

Odlaskom Supila u političku emigraciju i rad u Jugoslavenskom odboru te prestankom tiskanja Novog lista trebalo je ispuniti nastali vakuum pa Ružić kao ulazak u politiku navodi pokretanje Primorskih novina na Sušaku 1916. koje su uređivali Franjo Kučinić i Peroslav Ljubić. Za novine je pisao Jovo Miodragović, raniji suradnik Srbobrana iz Zagreba, vjerojatno Novog Srbobrana koji je pokrenuo Pribićević, a ne protuhrvatski usmjerenog starijeg Srbobrana. Ružić se uključio u krug zagrebačkih političara jugoslavenskog usmjerenja (Mate Drinković, Ivan Krstelj, Srđan Budisavljević, Grga Anđelinović, Roko Joković) koji od konca 1917. izdaju Glas Slovenaca, Hrvata i Srba. Bio je član Odbora i tajnik Narodne čitaonice u Rijeci, središta narodnog pokreta. ${ }^{19}$

Važni su podatci o raspadu Austro-Ugarske i nastanku narodnih vijeća Slovenaca, Hrvata i Srba. To doba započinje napomenom o Svibanjskoj (Majskoj) deklaraciji od 30. svibnja 1917., kojom 30 zastupnika iz Carevinskog vijeća, predstavničkog tijela u austrijskom dijelu Monarhije, traži ujedinjenje južnoslavenskih područja unutar Monarhije u treće državno tijelo, tzv. trijalizam. Pozivaju se na pravo naroda

15 Ružić, Moje uspomene, str. 6. O opravdanosti takvog razmišljanja govori i izjava cara Franje II. (1792.-1835.): "Moji su narodi tuđi jedni drugima i tim bolje. Kada u Francuskoj dođe groznica, spopadne sve u jedan dan. Ja metnem Mađare u Italiju, Talijane u Mađarsku. Svak čuva svog susjeda; oni se ne razumiju i mrze. Od njihove protivnosti nastaje red, a od njihove uzajamne mržnje opći mir”. Krišković, Jedan vijek političkih ideja vodilja, Zagreb, 1936., str. 4., prema Engelsfeld, N., Povijest hrvatske države i prava, Zagreb, Pravni fakultet u Zagrebu, 2002, str. 58.

16 Ružić, Moje uspomene, str. 6-7. I tu se očituje Supilov utjecaj i obraćanje Ujedinjenoj nacionalističkoj omladini kako bi izbjegli ekskluzivizam Srba u Hrvatskoj na štetu hrvatskih interesa. Supilo, Politički, str. 53-54, članci: Politika u Hrvatskoj, str. 407-419 i Nagodbenjačka politika i Srbi u Hrvatskoj, str. 420-424.

17 Bartulović i Ranđelović, Osnovi, str. 136-137.

18 Ružić, Moje uspomene, str. 8.

19 Ibid., str. 9-10. Vidi i Despot, M., Pokušaj bibliografije primorskih novina i časopisa 1843.1945., u: Rijeka, Zbornik, Zagreb, Matica hrvatska, 1953, str. 628. 
na samoodređenje, a za hrvatske zemlje i na hrvatsko državno pravo. Nakon toga, sredinom 1918. dolazi do osnivanja narodnih vijeća Slovenaca, Hrvata i Srba, političkih tijela koja podržavaju reorganizaciju, a potom izlazak iz Monarhije te stvaranje države južnih Slavena. ${ }^{20}$

Krug osoba povezanih s novinama Glas SHS (Krstelj, Drinković i Srđan Budisavljević) odabrao je dr. Ružića za pripremu utemeljenja narodnih vijeća u Hrvatskom primorju. Važna je zabilješka prema kojoj Budisavljević traži da se umjesto termina „Jugoslaveni “ koristi „Srbi, Hrvati i Slovenci“ jer to „poruka iz vana“. Srbijanski političari, predvođeni radikalima, tj. Pašićem nisu htjeli „utopiti“ srbijansko ime i državnost u jugoslavenstvu, pa su dali naputak Srbima Prečanima da postupaju u tom smjeru. ${ }^{21}$

Memoari donose podatke o sastanku u kući Ružić kojim je predsjedavao Viktor Car Emin, spominje se i dr. Sobol i drugi. Utemeljena je Narodna organizacija Hrvatskog primorja i Istre. Ipak, datum ostaje dvojben, jer je Ružić prvo napisao „, 14. VII ", a potom precrtao jednu jedinicu u mjesecu pa bi to značilo 14. lipnja. Predsjednik je postao Rikard Lenac, a tajnici Milivoj Korlević, August Juretić i Ružić. Andre Bakarčić zabunom je nepozvan pa je nakon što je prosvjedovao uvršten među nazočne. Primorske novine objavile su vijest o tomu, a za izbjegavanje cenzure zaslužan je žandarmerijski potpukovnik Misler. Riječ je Milanu Miesleru, kasnijem zapovjedniku oružništva NDH. Mjesec dana nakon toga utemeljeno je i Narodno vijeće za Rijeku i Sušak čiji je predsjednik bio Andre Bakarčić. ${ }^{22}$ Pitanje točnog vremena utemeljenja izaziva prijepore. Pomno iščitavajući Ružićev tekst, iako je pisan nakon 50 godina, u njemu ne nalazimo pogreške. Treba pretpostaviti da je razlikovanje dva sastanka i dvije organizacije narodnog vijeća ipak točno i treba mu dati prednost za razliku od mišljenja u drugoj literaturi.

Do stvaranja Središnjeg narodnog vijeća SHS došlo je u Zagrebu 5./6. listopada 1918., a dr. Ružić bio je predstavnik tzv. Grupe oko Glasa S.H.S. zajedno s Budisavljevićem i Valerijanom Pribićevićem, bratom Svetozara Pribićevića. ${ }^{23}$ Narodno vijeće bilo je politički predstavnik južnoslavenskih naroda na području Austro-Ugarske. Tek istupom Hrvatske iz Austro-Ugarske 29. listopada 1918. nastaje Država SHS, a Narodno vijeće postaje tijelo vlasti. ${ }^{24}$

Uz preležanu „španjolsku groznicu“, Ružić piše o pobuni 79. regimente, ,jelačićevaca“, pukovnije iz Otočca protiv mađarske vlasti i pomoć u odvođenju pobunjenika u Zeleni kadar kako bi izbjegli kazne. ${ }^{25}$ Ova pukovnija bila je „trn u oku" protivnicima hrvatskog nacionalnog pokreta (mađaronima i iredentistima) i prije rata. Godine 1918., 23. listopada njezini predstavnici na Sušaku od Narodnog vijeća dobivaju hrvatsku zastavu i sukobljavaju se s mađarskim vojnicima - ,honvedima “ $\mathrm{i}$

20 Bartulović i Ranđelović, Osnovi, str. 155-156 i 158.

21 Ružić, Moje uspomene, str. 11-12. Vidi Bartulović i Ranđelović, str. 182.

22 Ružić, Moje uspomene, str. 12. Vidi Bartulović, Sušak, str. 41.

23 Ružić, Moje uspomene, str. 12.

24 Bartulović, Povijest, str. 74-75. Zanimljivo je da je Hrvatsko-srpska koalicija na čelu sa Svetozarom Pribićevićem koja je imala prevlast u Hrvatskom saboru zadnja pristupila Narodnom vijeću 8. listopada 1918. i vodila oportunističku politiku blisku interesima Srbije.

25 Ružić, Moje uspomene, str. 13; Horvat, J., Politička, dio II., str. 76. 
riječkim redarstvom. ${ }^{26}$

Ružić obrazlaže pravno pitanje preuzimanja vlasti u Rijeci po povjereniku Narodnog vijeća, kotarskom predstojniku Sušaka Konstantinu Rojčeviću, od guvernera Jekelfalusya. Narodno vijeće SHS za velikoga župana riječkoga imenovalo je odvjetnika dr. Rikarda Lenca. On se 3. studenog sastao s gradonačelnikom Rijeke, dr. Viom, a sutradan su trebali zajedno krenuti ususret talijanskoj, formalno savezničkoj floti, ali Vio je otplovio sam. Talijanski admiral Rainer nakon dolaska posjetio je župana i izrazio zabrinutost za sigurnost Talijana u Rijeci, što je bio uvod u kasnija događanja. Rijeku su tada posjetila dvojica ,povjerenika“, tj. ministara u vladi Države SHS, dr. Tresić-Pavičić i za socijalna pitanja Vilim Bukšeg. ${ }^{27}$

U sjećanjima je precizno naveden dan dolaska srbijanske postrojbe pod zapovjedništvom potpukovnika Maksimovića - 15. studeni 1918. Admiral Rainer tražio je da u Rijeku uđe i talijanska vojska, a na pregovorima su sudjelovali major (bojnik) 79. regimente Petar Teslić i tadašnji kapetan korvete, kasniji doktor pomorskog prava i prvi dekan Pravnog fakulteta u Rijeci, dr. Emanuel Dworski. Postignut je sporazum da se srbijanska postrojba povuče iz grada, ali tijekom evakuacije talijanska vojska prijevarno ulazi u grad uz poziv talijanskoga Consiglio Nazionalea. General San Marzano uz prosvjede preuzima vlast od župana Lenca. ${ }^{28}$ Time je započela višegodišnja formalno antantina, međusaveznička, a zapravo talijanska okupacija Rijeke i Sušaka radi priključenja ovih krajeva Italiji. Italija se pozivala na toč. 5.b Ugovora o primirju s austrougarskim vojnim stožerom koji im je omogućavao zaposjedanje čitave jadranske obale, ali su kršili toč. 6., koja ih je obvezivala poštovati mjesna tijela vlasti. Dvojbena je i uloga potpukovnika Ljubomira Maksimovića. Treba napomenuti da ga Ružić imenuje kao Vojina. Riječ je zabuni jer je drugi general, prezimenjak prvospomenutoga. ${ }^{29}$ On je 17 . studenoga napustio Rijeku „po višem nalogu”, jer režimu u Beogradu nije stalo do ovog prostora. Maksimović u izvješću kritizira osnivanje Države SHS, zamjerajući što nije došlo do priključenja tih krajeva Srbiji. ${ }^{30}$

Tijekom Prvoprosinačkog akta ujedinjenja dr. Ružić je bio u Zagrebu gdje mu se rodila kćer, a potom odlazi u Beograd. Tijekom putovanja u vlaku odgovarajući na pitanje svećenika Slovenca tko će biti predsjednik prve vlade nove države, odgovora: „....svakako da će to biti Pašićc", i nakon 50 godina pamti repliku: „...onda né́e biti Jugoslavije“. Ružić naglašava da tada nije bio upoznat s nesuglasicama Pašića

26 Bartulović, Sušak, str. 41.

27 Ružić, Moje uspomene, str. 13-14. Bartulović, Sušak, str. 42-44.

28 Ružić, Moje uspomene, str. 14-15.

29 Bartulović, Sušak, str. 44-48. Vidi Bjelajac, M. S., Generali i admirali Kraljevine Jugoslavije 1918-1941., Beograd, Institut za noviju istoriju Srbije, 2004, str. 200-201.

30 Bartulović, Ž., Grobnišćina 1918. - raspad Austro-Ugarske i talijanska okupacija, Rijeka, Grobnički zbornik, 9/2013, str. 61-75; Perović, I. V., Crtice iz okupiranog Sušaka, Sušak, Primorski štamparski zavod, 1932, str. 24-28 i Kolar, M., Dokumenti o vlasti Narodnog vijeća Države SHS nad Rijekom - listopad/studeni 1918. g., Rijeka, Vjesnik DAR, 41-42/2000, str. 33. "Ovom prilikom čast mi je izvestiti komandanta da je svo stanovništvo uvidelo grešku političara što su proglasili državu Slovenaca, Hrvata i Srba, međutim trebali su po mišljenju sviju, da se priključe Kraljevini Srbiji na podlozi Krfskoga pakta." 
i Jugoslavenskog odbora. ${ }^{31}$ Pašić je Jugoslavenski odbor od 1915. pokušavao staviti pod svoj nadzor, imali su različite poglede na oblik vladavine i uređenje buduće države koji su došli do izražaja na Krfskoj konferenciji 1917. te Ženevskoj konferenciji 1918. Ironija sudbine bila je ta da je regent Aleksandar želeći pokazati da će on biti presudan čimbenik u novoj državi odlučio da prvi predsjednik vlade bude radikal, ali ne Pašić, nego Stojan Protić. ${ }^{32}$

Ružić prilazi krugu koji radi na utemeljenju Demokratske stranke, upoznaje srbijanske političare Ljubu Davidovića i Jovana Jovanovića. Svjedoči inicijativnom sastanku 23. prosinca 1918. u prostorima lista Glasa SHS. Pribićević zagovara osnivanje, a odvjetnik Jozo Sunarić, raniji predsjednik Bosanskog sabora, kasnije osnivač Hrvatske težačke stranke i doglavnik u NDH, upozorava da se zajednička stranka ne stvara žurno, nego je bolje stvoriti koaliciju demokratskih prečanskih i srbijanskih stranaka, jer unutar srbijanske političke scene postoje stari, neriješeni sukobi u koje „prečani“ ne trebaju ulaziti. Prevladao je Pribićević i nova stranka, jugoslavenskog usmjerenja, utemeljena je početkom 1919. u Sarajevu. ${ }^{33}$

Pribićević je u siječnju 1919. umirivao Ružića da Rijeka neće pripasti Italiji jer nije obećana Londonskim ugovorom 1915. Izaslanstvu Kraljevstva SHS na mirovnoj konferenciji u Parizu pridodani su pojedinci sa Sušaka, Rikard Lenac, Bogdan Durbešić, direktor pomorskog društva Ungaro-Croate i trgovac Alberto Bonetić. ${ }^{34}$ Točno je da Rijeka nije bila obećana Italiji, ali događaji su krenuli drugim smjerom.

Dr. Ružić također je sudjelovao na konferenciju u Parizu u svibnju 1919. upućen po pitanju podjele austrougarskih trgovačkih brodova između saveznika kao naknade štete za njihove potopljene brodove. Navodi da ga je ministar vanjskih poslova dr. Trumbić obavijestio da su sklopljeni sporazumi prema kojima su brodarska društva s većinskim hrvatskim kapitalom pripala novoj državi, Kraljevstvu SHS. ${ }^{35}$ Ipak, to nije bilo tako jednostavno, niti povoljno riješeno. Velika Britanija osobito je bila zainteresirana za nadoknadu svoje štete, pa je namirila svoje interese. Hrvatski brodari tražili su da se njihovi brodovi izuzmu od oduzimanja jer su nakon 1918. postali dio savezničke države. Talijani su pak jeftino otkupljivali dionice mađarskih vlasnika koji su znali da će izgubiti brodove, mijenjali vlasničku strukturu društava i potom prikazivali brodove kao talijanske kako ne bi bili oduzeti po saveznicima za naknadu. Pregovori s Italijom, tzv. sporazumi Trumbić-Bertolini vodili su se do 7. rujna $1920 .{ }^{36}$

Ružić piše da je u Parizu sazrio njegov negativan sud o radu političkih stranaka pa i Demokratske čiji je bio član bio, osobito kada je vidio da sprovode agrarnu reformu ,nagrađujući svoje pristaše zemljom “. Po povratku javlja dr. Budisavljeviću 25. svibnja 1919. da istupa iz stranke, te nakon toga više nikada nije bio član niti jedne

31 Ružić, Moje uspomene, str. 16.

32 Bartulović i Ranđelović, Osnovi, str. 153-162 i 170.

33 Ružić, Moje uspomene, str. 17. Vidi i Bartulović i Ranđelović, Osnovi, str. 181.

34 Ružić, Moje uspomene, str. 17. Londonskim ugovorom od 26. travnja 1914. su države Antante obećale određene teritorijalne ustupke Italiji ako uđe u rat na njihovoj strani. Obećani su i hrvatski prostori, tako Istra, Cres i Lošinj, manji kvarnerski otoci, te Dalmacija od Starigrada do rta Ploče između Šibenika i Trogira. Vidi Bartulović, Povijest, str. 71.

35 Ružić, Moje uspomene, str. 18. Vidi i Bartulović, Sušak, str. 51-54.

36 Ibid., str. 54-56. 
stranke. ${ }^{37}$

Izlazak iz stranke ipak nije značio prestanak rada u još uvijek aktivnom Narodnom vijeću na Sušaku. On nastavlja razmjenjivati informacije s francuskim i engleskim časnicima te potajno prati aktivnost talijanskih časnika u sastavu međusavezničkog zapovjedništva. Precizno navodi da je pribavljen popis naoružanja koje je talijanska vojska predala iredentistima u Rijeci, a kojima je izvršen kasniji napad na francuske vojnike Anamite i Narodnu čitaonicu. ${ }^{38}$ Narodna čitaonica devastirana je sredinom lipnja 1919., a tzv. „riječki legionari“" napali su francuske vojnike Anamite 6. srpnja 1919. u luci Baroš i ubili njih 13. Međusavezničko povjerenstvo ispitalo je incident. Ružić ističe podršku francuskih i engleskih, ,a donekle $i$ američkih vojnih vlasti“. Upoznao je povjerenstvo s popisom oružja koje je talijansko zapovjedništvo dalo Talijanima. ${ }^{39}$

Još nesretnije doba slijedi ulaskom Gabriellea D'Annunzia u Rijeku 12. studenoga 1919., proglašenjem Talijanske Regencije Kvarnera i vojnim protjerivanjem iz Rijeke na, tzv. „,krvavi Božić“ 1920., pokušajem stvaranja Riječke države na čelu s Ricardom Zanellom i rješenjem „riječkog pitanja“ Rimskim ugovorima između Italije i Kraljevine SHS 27. siječnja $1924 .{ }^{40}$ No, veći dio tih važnih zbivanja autor u svojoj biografiji preskače. Navodi da je položio pravne ispite tijekom 1920. i 1921., s rigorozima, a 17. ožujka 1921. promoviran je u doktora prava. Pokušavao se vratiti na Sušak, ali talijanski predstojnik redarstva nije to dopustio uz obrazloženje da se iseljenici ne mogu vratiti zbog nedostatka hrane, pa je stoga potajno prešao crtu razgraničenja sredinom 1920., a tek početkom 1921. dobio dozvolu za povratak. ${ }^{41}$ Ipak, razlozi su bili nešto drukčiji, talijanskoj okupacijskoj vlasti bilo je u interesu da se što više osoba koje su emigrirale ne vrate u Rijeku i Sušak jer bi tako izmijenile nacionalnu strukturu ovog područja. ${ }^{42} \mathrm{U}$ konkretnom slučaju dodatno je bilo poželjno odstraniti politički važnu osobu.

Dr. Ružić uočio je važnost pitanja stvaranja zajedničkog lučkog konzorcija Italije, Kraljevstva SHS i Riječke države te se na sastancima u vladi u Beogradu s Pašićem, Trumbićem i Laginjom zalagao protiv toga. Memorandum o tom pitanju izradio je Aurel Figatner 20. lipnja 1921. u jeku rasprava o donošenju Vidovdanskog ustava. ${ }^{43}$ Putem naizgled dobrog prijedloga gospodarskog povezivanja svih lučkih postrojenja, talijanska strana htjela je onemogućiti rad riječke i sušačke luke. Odluke u konzorciju donosio bi Upravni savjet u kojem bi Italija, Kraljevstvo SHS i Riječka država imali po dva predstavnika. Riječke članove birali bi Italija i Kraljevstvo SHS po jednoga.

37 Ružić, Moje uspomene, str. 18. Tijekom ispitivanja po OZN-i 1945. izjavio je da je i kasnije glasovao za nju. U: Život koji teče, str. 159-160. O agrarnoj politici u Kraljevini SHS vidi Bartulović, Povijest, str. 102-103.

38 Ružić, Moje uspomene, str. 17.

39 Ibid., str. 19. Odlukom povjerenstva talijanska vojska trebala je zadržati samo jednu postrojbu u Rijeci, a red je trebala održavati britanska i američka policija. Ipak, to nije sprovedeno. Bartulović, Sušak, str. 47-48.

40 Bartulović, Povijest, str. 95-96; isti, Sušak, str. 48-50.

41 Ružić, Moje uspomene, str. 20. U zapisniku saslušanja OZN-e 1945. navodi da je izvan Sušaka bio od rujna 1919. do 1921., a ne spominje ovaj dolazak. U: Život koji teče, str. 159.

42 Bartulović, Sušak, str. 48.

43 Ružić, Moje uspomene, str. 20-21. 
Za donošenje važnijih odluka bila bi potrebna četiri glasa pa bi talijanska strana mogla uvijek zaustaviti odlučivanje i rad konzorcija. Njoj je to bilo u interesu jer je sušačka luka bila jedina uređena luka sa željezničkom prugom širokoga kolosijeka na istočnoj obali Jadrana, a najbliža druga luka bila je šibenska s uskotračnim kolosijekom. ${ }^{44}$

Dr. Ružić piše i o problemu zamjene austrougarske valute u nove jugoslavenske dinare. Stara valuta bila je u opticaju tijekom okupacije i zamjena je izvršena kasnije u odnosu na ostale krajeve nove države. Trebala je biti obavljena u lošijem omjeru od ostalih krajeva gdje je bila jedan dinar za četiri krune/forinte. Dr. Ružić navodi da je osobnom intervencijom u Beogradu uspio da se primjeni, barem taj tečaj. ${ }^{45}$ Izbacivanje stare valute iz uporabe i tečaj promjene izazvao je brojna negodovanja u prečanskim krajevima jer je beogradski režim otezao s uvođenjem novog dinara kako bi vrijednost novca u prečanskim područjima što više opala. Prije toga novčanice su se označavale žigom koji se lako krivotvorio, potom su uvedene „markice“ pri čemu se naplaćivala pristojba od $20 \%$ vrijednosti novca, dodatno je vlada u Beču kupila nove novčanice od 300 milijuna kruna, a stare nije povukla. Time je beogradski režim i kapital rušio gospodarsku i novčarsku konkurenciju prečanskih krajeva. Vrhunac licemjerja bio je sadržan u Nettunskim konvencijama 1925. kojim su rješavana razna pitanja nakon razgraničenja i prestanka postojanja Riječke države. Prema Konvenciji o dugovima $i$ potraživanjima za dugove državljana Kraljevine SHS nastale prije 3. studenog 1918. ovaj je odgovarao prema talijanskom tečaju kojim je talijanski vjerovnik dobivao $90 \%$ vrijednosti duga. Nasuprot tomu, ako je dužnik bio Talijan, primjenjivao se jugoslavenski tečaj, prema kojem je vjerovnik dobivao samo $25 \%$ vrijednosti duga do 1918. godine. ${ }^{46}$

\section{RUŽIĆ U POLITICI OD 1925. DO 1941.}

Ono što bi bilo zanimljivo pročitati iz pera dr. Ružića su razmišljanja o izborima, ali on se osvrnuo tek na skupštinske izbore 8. veljače 1925., kada je imenovan predsjednikom izbornog povjerenstva na Kastavštini. Primjetne su njegove kritike upućene vladajućem režimu, tzv. „PP vladi“, koaliciji Pašićevih radikala i Pribićevićeve Samostalne demokratske stranke. Upozorava da nije dobio akt o svom imenovanju pa je na biračko mjesto došao s primjerkom Službenih novina pozivajući se na njega da bi tek tada bio pripušten jer ,se želilo, da izbori budu provedeni sa dobronaklonošću za vladine kandidate ", bez nadzora članova povjerenstva u koje se nije imalo povjerenja.

Na izborima za Ustavotvornu skupštinu 1920. nije se glasovalo u Gradu Sušaku koji je bio okupiran, već samo u neokupiranom dijelu kotara. Birači u kotaru većinu su glasova dali komunistima i demokratima, a u županiji demokratima i Radićevim „seljacima“. Na izborima za državnu skupštinu 1923. u gradu i kotaru Sušak većinu je dobila Nezavisna jugoslavenska lista na čelu s Jurajem Kučićem koja se odvojila od Demokratske stranke, dok su u županiji najjači bili „radićevci“. Na izborima 1925.,

44 Bartulović, Sušak, str. 65-68.

45 Ružić, Moje uspomene, str. 21.

46 Bartulović i Ranđelović, str. 169-170; Bartulović, Sušak, str. 85. 
kao i ranije, dosta se upozoravalo na namještanje rezultata, jer se glasovalo kuglicama koje su se mogle bez traga prebacivati iz jedne u drugu biračku kutiju. U gradu Sušaku pobijedili su demokrati, kao i na Kastvu, a PP koalicija ostala je iza njih. Na razini županije pobijedili su ,radićevci“, ispred PP koalicije. Demokratska struja bila je jaka u Sušaku, a od 1925. jača Radićeva H(R)SS. ${ }^{47}$

Ružić ulazi u upravu novoga brodarskog društva Jadranska plovidba d.d. u Sušaku. ${ }^{48}$ Radi kao njen odvjetnik, a vodio je važne sporove iz oblasti trgovačkog prava, npr. likvidaciju imovine nekadašnjeg brodarskog društva Ungaro-Croata, koja nije ušla u novo društvo. Spominje i stečaj Banke i štedionice za Primorje, tzv. Litoralke u kojoj se nalazila imovina negdašnjeg društva. ${ }^{49}$ Propast banke dijelom je uzrokovana lošim ulaganjima u dionice Jadransko-podunavske banke sa sjedištem u Beogradu, ali ta je banka dovela do propasti nekoliko prečanskih banaka pa se govorilo o udaru beogradskih novčarskih krugova, bliskih vladi na ovdašnje bankovne institucije. ${ }^{50} \mathrm{U}$ svom odvjetničkom radu Ružić ističe zastupanje Jadranske plovidbe u sporu naknade štete izazvane sudarom parobroda Karađorđe s talijanskim Morosini 1930. i koji je uspješno dovršen nagodbom. ${ }^{51}$

O atentatu na Stjepana Radića Ružić šturo navodi da su „,zatrovane političke prilike“, ali je uvođenje Šestosiječanjske diktature ocijenio ovako: „I ako ne volim diktature, držah da je to u danim prilikama za očuvanje zemlje od težih posljedica bio najbolji izlaz. " 52 Možda će procjena zvučati monarhistički i nehrvatski, ali i dr. Maček je rekao: „Lajbek je raskopčan. “, aludirajući da je dotadašnje uređenje loše pa će se kraljevskom intervencijom moći ispraviti. No, ubrzo je izgubio iluzije o mogućim promjenama putem diktature.

Dr. Ružić izašao je na skupštinske izbore 1931. kao zamjenik Vjekoslava Spinčića, dok im je protukandidat bio sušački novinar i publicista Milan Banić. U izbornoj jedinici pobijedio je Spinčić, koji umire 1933., kada ga je Ružić zamijenio u skupštini. Ružić je radi sukoba interesa, napustio upravu Jadranske plovidbe jer je tvrtka primala državne subvencije. Kao uspjeh u radu ističe da se izborio za mirovine radnicama nekadašnje tvornice duhana u Rijeci, tzv. ,, paltaricama “. ${ }^{53}$ Izbori 8. studenog 1931. nisu bili demokratski. Nakon što su diktaturu kritizirale Velika Britanija i Francuska koje su štitile ulaganja u Jugoslaviji, svjetske gospodarske krize i političkog nezadovoljstva u zemlji kralj Aleksandar Karađorđević oktroirao je ustav 3. rujna 1931. godine. Političke stranke nisu imale vremena pripremiti se za izbore, a

47 Ibid., str. 91-100.

48 Ružić, Moje uspomene, str. 21.

49 Ibid., str. 22-23.

50 Bartulović, Sušak, str. 219-222; id., Stečaj Banke i štedione za Primorje ("Litoralke")", Rijeka, Sveti Vid: zbornik, VII/1995, str. 71-84.

51 Ružić, Moje uspomene, str. 23-24.

52 Ibid., str. 23.

53 Ibid., str. 25. Vidi i saslušanje OZN-e u: Život koji teče, str. 160-161 gdje ističe da nije bio pripadnik ni jedne stranke niti skupštinskog kluba. O pitanju mirovina „paltarica“ koje su godinama tražile svoje mirovine ostvarene radom do 1918. koje je Italija kao pravna sljednica obveze trebala plaćati i nemarnosti vlade u Beogradu spram ostvarenja njihovih prava prema „,Sporazumu o pensijama“, u Nettunskim konvencijama 1925. Vidi i Bartulović, Sušak, str. 7980. 
k tome su izborni propisi predviđali sustav, tzv. „Zemaljskih lista“ što znači da je lista morala imati kandidate u svakom od 301 izbornog kotara, a to je za manje, nacionalne ili regionalne stranke bilo nemoguće, osim u koaliciji, a za to nije bilo vremena. $\mathrm{Na}$ izbore je izašla samo vladina lista, generala Petra Živkovića, čiji su kandidati bili Spinčić i Ružić, ali i Banić jer su bili protukandidati na istoj, vladinoj listi. Zbog toga se za te izbore popularno kaže da su bili ,izborna utrka s jednim konjem“ “. ${ }^{54}$

Ružić je ostao zastupnik do izbora 1935., a u tom razdoblju ističe upoznavanje s dr. Antonom Korošecom, svećenikom, predsjednikom Slovenske ljudske stranke, bez čega bi ,,kasniji moj život sigurno bi drugačije tekao. "55 Ružić navodi da je 1934. putovao iz Beograda za Sušak i u Zagrebu susreo Stanka Švrljugu, disidenta HSS-a, ministra financija tijekom diktature 1929., koji je išao u posjet Korošecu, interniranom od vlasti u Hvaru (1932.-1934.). Korošec ga je, naime, kasnije predložio za bana i ministra. ${ }^{56}$

Ružić ističe kako je 1934. branio 18 mladića, uglavnom s Hreljina koji su pred sudom u Ogulinu bili optuženi za komunističku aktivnost, pri čemu ga je ,, revoltirao postupak istražnih organa prema njima ", a zalagao se i da po odsluženju presude dobiju posao. Za obranu nije primio honorar, osim boce pića i jednog sira, ali osjeća se povrijeđenost kada navodi da je nakon rata ,narodna vlast“ istraživala koliki je honorar dobio. ${ }^{57}$

Slijedi doba kada je karijera Viktora Ružića doživjela zenit. U veljači 1936. predsjednik vlade Stojadinović ponudio mu je mjesto bana Banovine Savske, a imenovan 26. travnja 1936. To je bilo uzburkano doba, 16. travnja došlo je do krvoprolića u Kerestincu gdje su seljaci ubili petoricu ljudi u dvoru bivšega hrvatskog bana Mihalovića jer su ih smatrali četnicima. ${ }^{58}$ Ružić svoje banovanje ocjenjuje nastojanjem , po mogućnosti političke sukobe eliminirati “ umirivanjem nepotrebnih sukoba, npr. nekažnjavanjem i nenaplaćivanjem kazni za isticanje hrvatske zastave. Navodi da je knezu Pavlu opisao , uspjeh u smirivanju duhova... što sam malko pritegnuo policijske vlasti, koje su na ispade opozicije prestrogo reagirali. "59 Upozorava da je do sukoba po selima dolazilo i zbog provokacija hrvatske Seljačke zaštite koja nije pokazivala tolerantnost prema seljacima koje su smatrali suradnicima režima. Stoga je pojačao broj ophodnji žandara, što je izazvalo negodovanje dr. Mačeka.$^{60}$ Ovakav zapis govori o Ružićevom pokušaju nalaženja kompromisa između interesa vlasti i očuvanja države s jedne strane i kakve-takve zaštite hrvatskih interesa

54 Bartulović, Povijest, str. 98-99; id., Sušak, str. 116.

55 Ružić, Moje uspomene, str. 25.

56 Vidi saslušanje OZN-e u: Život koji teče, str. 159 i 179.

57 Ružić, Moje uspomene, str. 26. Spomen o tome u: Janjatović, B. i Strčić, P., Žandarmerijski istražni spisi iz 1934. godine o članovima i simpatizerima KPJ u Hrvatskom primorju, Rijeka, Vjesnik Historijskih arhiva u Rijeci i Pazinu, XVIII/1973, str. 163.

58 Ružić, Moje uspomene, str. 27. Nekadašnji ban Antun Mihalović bio je čelnik kvazivojne organizacije ,plave košulje“ Milana Stojadinovića na hrvatskim prostorima. Njihovi pripadnici, odnosno ,jugorasovci“ (JUGORAS - Jugoslavenski radnički sindikat) bliski su idejama fašizma, a u konkretnom slučaju izazvali su reakciju hrvatskih seljaka uzvikivanjem parola protiv HSS-a i Vladka Mačeka.

59 Ružić, Moje uspomene, str. 28.

60 Ibid., str. 29-30. 
pa nije uputno okarakterizirati ga isključivo pobornikom jugoslavenstva, osobito unitarnoga.

Možda je najdvojbenije pisanje o tzv. „senjskim žrtvama“, krvoproliću u Senju 9. svibnja 1937., kada su žandari pucali na Hrvate iz Gospića koji su došli na skup prigodom gostovanja Hrvatskog pjevačkog društva Trebević iz Sarajeva. Hrvatska historiografija događaj kvalificira izrazito protuhrvatskim, dijelom isprovociranim od kotarskog načelnika i žandara. Život je izravno ili od posljedica ranjavanja izgubilo osam mladih osoba ${ }^{61}$ Ružić, događaj objašnjava spletom nesretnih okolnosti, hitcem žandarmerijskog kapetana (Koprivice, op. aut.), u gume kamiona pri čemu je pao, dok su žandari zapucali na kamion misleći da se pucalo na njega. Kapetan , koji je čitavu nesreću skrivio“ premješten je u Crnu Goru gdje su ga odmetnici (,kačaci“) ubili nakon dva mjeseca. ${ }^{62}$

Ružić upozorava i na posljedice vanjske politike Velike Britanije prema Jugoslaviji 1936. koja Jugoslaviju kritizira zbog približavanja Njemačkoj i Italiji, iznoseći mišljenje da je umjesto kritika bolje ostvariti trgovačke veze kako bi se pomoglo Jugoslaviji i oporavku njenoga gospodarstva. ${ }^{63}$ Nakon talijanske agresije na Etiopiju 1935., Društvo naroda uvelo je sankcije protiv nje. Zabrana trgovine utjecala je jugoslavensko gospodarstvo, npr. na trgovinu drva pa su knez Pavle i Stojadinović tražili od Velike Britanije jačanje trgovačkih veza, ali ona se pozivala na slobodan odabir trgovačkih partnera svojih gospodarstvenika. Stoga jača trgovina s Hitlerovom Njemačkom, koja u ožujku 1936. vojskom ulazi u dotada demilitariziranu Rajnsku oblast. Nakon toga slijedi približavanje fašističkoj Italiji potpisivanjem Ugovora o prijateljstvu 25. ožujka 1937., tzv. sporazum Ciano-Stojadinović. ${ }^{64}$

Ministar unutarnjih poslova Korošec, 14. kolovoza 1938. upozorio je Ružića da zbog nepodupiranja vladajuće Jugoslavenske radikalne zajednice neće dobiti njenu podršku na sljedećim izborima. On je odgovorio da kao ban drži da treba biti ,, posvema neutralan“, da je dužnost bana preuzeo „,pod uvjetom, da ne ulazi u stranačku politiku“. Ružić zbog toga daje ostavku i 24. kolovoza 1938. napušta dužnost. Vraća se na Sušak u studenome 1938. i posvećuje odvjetništvu, ali ne zadugo. ${ }^{65}$

Nakon tijesne pobjede Stojadinovića na skupštinskim izborima 11. prosinca

61 Npr. Manojlović, K., Događaji u Senju 9. svibnja 1937., Senj, Senjski zbornik, 18/1991, str. 237-258.

62 Ružić, Moje uspomene, str. 30. Ružić netočno navodi da se događaj zbio 9., ali ne svibnja nego listopada.

63 Ibid., str. 31. Ružić u tekstu koristi izraz „,zemljama osovine“ iako je naziv „Osovina“ RimBerlin nastao kasnije potpisivanjem ugovora o prijateljstvu između Njemačke i Italije 25. listopada 1936.

64 Bartulović i Ranđelović, Osnovi, str. 194-195.

65 Ružić, Moje uspomene, str. 31. Jugoslavenska radikalna zajednica - JRZ utemeljena je u kolovozu 1935., a provodila je politiku jugoslavenstva i centralizma, ali nešto umjerenije od ranije Jugoslavenske nacionalne stranke pod vodstvom Bogoljuba Jevtića. Čelnik JRZ-a bio je Milan Stojadinović. Bartulović i Ranđelović, str. 192. Gulić, M. i Lovrek, Z., Dr. Viktor Ružić ban Savske banovine (1936.-1938.), u: Život koji teče, str. 66-68 navodi da o napuštanju banske dužnosti postoji više tumačenja, da to nije bila njegova volja nego želja vlasti. Ipak bi trebalo pridati značaj njegovom zapisu da je to zbog nepodupiranja vlasti. Vidi saslušanje OZN-e u: Život koji teče, str. 159. 
1938., njegov položaj je uzdrman. Ružić bilježi susret sa Stjepanom Krasnikom, članom HSS-a, koji iznosi mišljenje da bi za sporazumijevanje s Hrvatima pogodna osoba bio Dragiša Cvetković, što on javlja Korošecu. Stojadinović „pada“ 4. veljače 1939., a Kraljevsko namjesništvo na čelu s knezom Pavlom mandat za sastav vlade daje Cvetkoviću. ${ }^{66}$ On je Ružiću 5. veljače ponudio ministarstvo trgovine, potom financija i konačno pravosuđa što je ovaj ,, rado prihvatio “. ${ }^{67}$

Ružić kao svoj doprinos ističe propis o nemogućnosti premještanja suca bez njegova pristanka, kao i ovisnost imenovanja o prijedlogu višeg suda, uvodi i sudske pristojbe za uređenje sudskih zgrada i uređenje gruntovnica, a nadzirao je i pritužbe o umirovljenju sudaca iz političkih razloga. Tvrdi da je u audijenciji kod pape Pia XII. u ožujku 1939. uvjeravao svetog Oca da je razlog neratificiranja konkordata između Vatikana i Jugoslavije sukob , uglavnom zbog unutrašnjih političkih prilika “, pri čemu čak i HSS time želi rušiti vladu, te i bez ratifikacije radi na provođenju svih načela konkordata bez ičijeg protivljenja ${ }^{68}$ Pitanje konkordata provociralo je političku scenu godinama. Prvi nacrt sastavljen je 1922., pregovori su obnovljeni od 1933. do 1935. kada je tekst potpisan za Stojadinovićeve vlade. Namjesništvo je ovlastilo vladu da tekst uputi Narodnoj skupštini. Reagirala je Srpska pravoslavna Crkva tvrdeći da je konkordat opasnost za pravoslavlje, a godine 1937. došlo je do obračuna protivnika s policijom u Beogradu, tzv. „krvava litija“. Konkordat je 23. srpnja izglasan u skupštini, ali tada umire patrijarh Varnava i crkveni sabor prijeti zatvaranjem crkava i ekskomunikacijom zastupnika u skupštini koji su za konkordat. Vlada tada odustaje od postupka. ${ }^{69}$

Ružić se prisjeća svog posredovanja kod spora između Prve hrvatske banke i štedionice koja je od Beogradske nadbiskupije potraživala dug u iznosu od čak dva milijuna dinara prijeteći sudskom tužbom i namirenjem iz biskupijskih nekretnina. Tvrdi da je putem kneza Pavla tražio da dio dužnog novca plati ministarstvo financija, a da dijelom odustane i banka. ${ }^{70}$

U sjećanju mu je ostao i prosvjed Ivana Ribara da se komunistima ,političkim zatvorenicima u Mitrovici... čine razna bezakonja. " Nakon provjere, uvjeravao ga je da oni uživaju „pogodnosti“ koje im je dao prethodni ministar pravosuđa Mile Miškulin pa imaju svoju literaturu, pišu letke, a zna da je Moša Pijade preveo Marksov Kapital. ${ }^{71}$

Knez Pavle dao je Cvetkoviću ne samo mandat za sastav vlade, već i za pregovore s oporbom, osobito s Mačekom kako bi se riješilo, tzv. „hrvatsko pitanje“. Nakon dovršetka pregovora donesena je Uredba o Banovini Hrvatskoj i još nekoliko

66 Smjeni Stojadinovića sigurno je doprinijelo približavanje Njemačkoj i Italiji što nije bilo po volji Velikoj Britaniji. Uhićen je, predan predstavnicima britanskih tajnih službi i interniran na otoku Mauricijusu gdje je proveo Drugi svjetski rat. Bartulović i Ranđelović, Osnovi, str. 193194.

67 Ružić, Moje uspomene, str. 33.

68 Ibid., str. 34-35.

69 Vidi npr. Ninčević, M. Marino i Brčić, F., Diplomatski odnosi Vatikana i Kraljevine Jugoslavije: konkordat iz 1935. godine, Zagreb, Nova prisutnost, XIV/2/2016, str. 299-307.

70 Ružić, Moje uspomene, str. 35.

71 Loc. cit. 
popratnih akata. Došlo je do stvaranja nove vlade Cvetković-Maček u koju Ružić nije ušao. ${ }^{72}$ Nakon sklapanja sporazuma Cvetković-Maček 26. kolovoza 1939. Ružić je ostavku smatrao moralnim činom. Nakon povratka na Sušak nije otvorio advokaturu, držeći neetičkim da to učini nakon što je bio ministar pravosuđa. Kao čelnika kabineta tijekom svog mandata istaknuo je više osoba, a među njima i Emilija Palluu, doktora pomorskog prava i kasnijeg suradnika Jadranskog instituta JAZU (današnjeg Jadranskog zavoda HAZU) u Rijeci. ${ }^{73}$ Ružić navodi da je vlada Cvetković-Maček uživala povjerenje hrvatskih i slovenskih birača, ali ne i Srba, pa je potrebno stvoriti „širu koncentracionu vladu“. O tome je govorio dr. Korošecu, ali bilo je prekasno jer je uslijedio državni udar 27. ožujka 1941 . $^{74}$

Ružić ističe da je predvidio točan datum ulaska Italije u Drugi svjetski rat, nakon što ga je u ožujku 1940. američki veleposlanik Bliss Lane pitao zna li išta o tom pitanju. Ružić je to povezao sa sjednicom Velikog fašističkog vijeća, zakazanoj za 10. lipnja. Igrom slučaja tog je dana bio na ručku diplomatskog kora kod francuskog veleposlanika u Beogradu, gdje ga je američki časnik javno podsjetio na izjavu, ali ona se do konca dana, na iznenađenje diplomatskog kora i ostvarila. ${ }^{75}$

\section{DR. RUŽIĆ U DRUGOM SVJETSKOM RATU 1941.-1945.}

Nakon pristupa Jugoslavije Trojnom paktu 25. ožujka 1941. uslijedio je državni udar 27. ožujka, ostavka Kraljevskog namjesništva i tek formalno preuzimanje vlasti od kralja Petra II. Stvarnu vlast preuzeo je general Dušan Simović u ulozi predsjednika vlade. Hitler nije prihvatio uvjeravanje Simovića da će poštovati uvjeta pakta, jer je bilo očito da je smjena vlasti ostvarena uz tihu podršku Velike Britanije koja je u tom trenutku sama (izuzevši Grčku) ratovala protiv Njemačke i Italije i žudila za pomoći drugih država. Ne treba smetnuti s uma pitanje odnosa prevratnika spram opstanka Banovine Hrvatske, iako je Simović i to potvrdio Mačeku. ${ }^{76}$ Njemačka i Italija napale su Jugoslaviju 6. travnja 1941., no sav teret napada preuzeo je Reich, dok je Mussolini čekao da Hitler obavi sav posao kako bi se uključio u podjelu plijena. Hitler je pokušao pridobiti Mačeka kao vođu hrvatskoga naroda, ali kada je on to odbio Mussolini nudi svog saveznika - Antu Pavelića. Slavko Kvaternik je 10. travnja proglasio NDH, a sljedećeg dana talijanska vojska prelazi preko Rječine na Sušak te iz drugih pravaca ulazi na jugoslavenski teritorij kada je praktično prestao vojni otpor. ${ }^{77}$

Za razliku od Prvog svjetskog rata Ružić se prijavio na opći poziv u vojsku računajući da je to bolje nego da ga Talijani uhite kao civila ako ratna sreća bude na

72 Bartulović i Ranđelović, Osnovi, str. 196-199.

73 Ružić, Moje uspomene, str. 36.

74 Ibid., str. 37. Druge političke opcije, slovenske, srpske, bošnjačke, crnogorske, pa čak i hrvatske (ustaške), kao i komunističke su u sporazumu o Banovini Hrvatskoj vidjeli samo ostvarenje hrvatskih težnji, ali ne i potpuno rješenje odnosa u državi. Vidi Bartulović, Povijest, str. 106107.

75 Ružić, Moje uspomene, str. 36.

76 Bartulović i Ranđelović, Osnovi, str. 199-203.

77 Bartulović, Povijest, str. 107-112; id., Sušak, str. 228-232. 
njihovoj strani. Na vijesti o proglašenju NDH reagirao je negativno, ${ }^{78}$ a s rasulom vojske 11. travnja vratio se kući s Krasice gdje je bio u žandarmerijskoj četi. Koristeći poznanstvo s ministrom Ninom Host Venturijem pokušao je utjecati da talijanska vlast odbaci denuncijacije Konzulata NDH u Rijeci i smanji broj uhićenja i internacija stanovnika Sušaka, ali ga je riječki prefekt Temistocle Testa ubrzo uhitio, na ,jedan $i$ pol dan". Protivio se preseljenju dotadašnjih državnih službenika u NDH ,što bi za njih moglo biti fatalno, jer bi sa svojim obiteljima u najmanju ruku pošli na nesigurno. "79 Rimskim ugovorima između NDH i Italije 18. svibnja 1941. Sušak, dio Gorskog kotara i velik dio hrvatske obale priključen je Italiji. Italija je organizirala svoju vlast i uvela svoje propise na ovim prostorima potičući iseljavanje Hrvata i talijanizaciju. ${ }^{80}$ Međunarodno pravo nije priznavalo aneksiju teritorija Italiji kao niti ostalih teritorija drugim državama Trojnog pakta (Njemačkoj, Mađarskoj, Bugarskoj i Albaniji), nije priznavalo postojanje NDH, već je Kraljevinu Jugoslaviju držalo postojećim subjektom međunarodnog prava, privremeno okupiranom do okončanja rata, kada će se na mirovnoj konferenciji određivati granice i sudbina država. ${ }^{81}$

Ružić nije mirovao u „nemirnim“ vremenima. Ostvario je vezu s izbjegličkom vladom Kraljevine Jugoslavije u Londonu putem otpravnika poslova veleposlanstva u Rimu don Nike Moscatella, a to je omogućio i dr. Anti Mandiću s kojim se sastajao u Opatiji. Izvješća je slao ministrima Srđanu Budisavljeviću, Mihi Kreku i drugima. ${ }^{82} \mathrm{Za}$ razliku od Mandića, Zvonimira Rihtmana i Milivoja Jambrišaka s kojima se sastajao u Sušaku i Voloskom te razgovarao o otporu okupatoru, on je bio pobornik legitimiteta, tj. očuvanja monarhije i nije htio surađivati s komunistima pa se udaljio od njih. Oni se spominju kao, tzv. Građanski odbor. ${ }^{83} \mathrm{~S}$ četnicima, konkretno vojvodom Jevđevićem,

78 Na saslušanju OZN-i izjavio je: „... smatrao sam tu zemlju kao jednu prolaznu stvar koja će pobjedom saveznika biti likvidirana. “ Život koji teče, str. 161.

79 Ružić, Moje uspomene, str. 37-38.

80 Bartulović, Sušak, str. 241-248 i 251-260.

81 Ibid., str. 234-237.

82 Ružić, Moje uspomene, str. 39. Dr. Ante Mandić, kasniji član ZAVNOH-a i AVNOJ-a, a od ožujka 1945. godine član je Kraljevskog namjesništva s Dušanom Sernecom i Srđanom Budisavljevićem. Jambrišak i Rihtman također su se pridružili antifašističkom pokretu, za razliku od Ružića. Dubrović, E., Viktor Ružić i jugoslavenska kraljevska vlada u Londonu, u: Život koji teče, str. 33 i 39. Boban Ružićeva izvješća ocjenjuje preciznima i konciznima s osudama pripadnika ustaške vlasti. Upozorava i na opasnost od jačanja komunističkog utjecaja. Boban, Lj., Hrvatska u arhivima izbjegličke vlade 1941.-1943, Zagreb, Globus, 1985, str. 406409 i 462-465 i 470-472.

83 Dubrović, Viktor Ružić, str. 36-37. Ružić to ne spominje u svojim zapisima, veći u saslušanju OZN-e gdje navodi i dr. Vladimira Švalbu te Božu Frančića kao sudionike razgovora. Vidi saslušanje OZN-e u: Život koji teče, str. 161 i 169. Mandić je u Prvom svjetskom ratu bio član Jugoslavenskog odbora, prišao antifašističkom pokretu, postao član AVNOJ-a i ZAVNOH-a i 1945. član Kraljevskog namjesništva. Strčić, P. i Polić, M., Prilog poznavanju segmenata djelovanja dr. Viktora Ružića temeljem korespondencije dr. Ante Mandića, u: Život koji teče, str. 74. Oni navode da su u odboru bili i Igor Mandić, sin Ante Madnića, dr. Ante Grgurina, dr. Đuro Červar i Milan Marjanović. Vidi i Giron, A., Zapadna Hrvatska u Drugom svjetskom ratu, Rijeka, Adamić, 2004, str. 63-64. Giron navodi da su povezani sa senjskim biskupom Ivanom Burićem i krčkim biskupom Josipom Srebreničem, neki i s britanskom obavještajnom službom SOE. Piše da je Ružić putem riječkog prefekta Teste tražio dozvolu za put u Rim kako bi bio 
nije htio kontaktirati 1943. godine. Smatrao je da su četnici ,, izgubili svako pravo na opstanak“ kada su se ,,dali u službu Talijana“. 84

Koncem 1941. ili početkom 1942. posjetio je fra Dominika Mandića koji mu je dao naputak franjevačkoga generala franjevcima u NDH od 24. srpnja 1941. u kojem je upozoravao franjevce da ne ulaze u politiku i ustaški pokret, ne sudjeluju u progonu Židova i Srba, te nasilnom prijelazu na katoličku vjeru i sl. Na saslušanju OZN-e navodi da je bio primljen i u audijenciju kod pape, u kojem je izložio iste kritike o zbivanjima u NDH. ${ }^{85}$

Nakon povratka u Sušak Ružić je ponovno uhićen u svibnju 1942. sa sinom Viktorom, a 22. rujna 1942. suđeno mu je zbog ,subverzivne propagande“. Branio ga je nekadašnji gradonačelnik Rijeke, dr. Antonio Vio. Oslobođen je, ali je poslan u internaciju u Montereale u pokrajini Abruzzi. ${ }^{86}$ Te događaje opširno opisuje, ali riječ je o osobnim doživljajima. Internacija je potrajala do svibnja 1943., kada se vraća kući.

Viktor Ružić u Sušaku dočekao je kapitulaciju Italije 3. rujna 1943. Svjedočio je brzim promjenama, dolasku partizana, a zatim i Nijemaca koji su organizirali vojnu upravu putem Operativne zone Jadransko primorje, priznajući je dijelom talijanskoga teritorija, ali utirući put i za svoje aspiracije. ${ }^{87}$ Ružić piše da su Nijemci ,, smatrali o talijanskoj vojsci do onda okupirani teritorij slobodnim od Italije, pa je za ovaj kraj stvoren komesarijat te je komesarom imenovan sušački advokat dr. Franjo Špehar $i$ to na predlog konzulata NDH“, a stvorena je i „,naša gradska uprava sa načelnikom Mirom Kolaciom na čelu " ${ }^{88}$ To nije u potpunosti točno. Kako je NDH pretendirala da poništi Rimske ugovore iz 1941. i Sušak priključi sebi, Nijemci su dopustili da se na Sušaku utemelji Hrvatsko mjesno zapovjedničtvo, kao redarstvo, ali pridjev „hrvatsko“ označavao je samo narodnu, a ne državnu pripadnost. Za prostor anektiranih krajeva od Sušaka do Bakarca, Čabra i Krka ukinuta je dotadašnja talijanska Intendanza civile per i territori annessi del Fiumano e della Kupa, a 11. rujna 1943. njemački povjerenik Operativne zone, Friedrich Alois Reiner utemeljio je Upravno povjereničtvo SušakKrk koje nije smjelo isticati državna obilježja NDH, a izričito je navedeno da je i dalje dio Kvarnerske pokrajine. Špehar je bio na čelu Povjereništva, a imenovan je i za

primljen u audijenciju kod talijanskoga kralja.

84 Vidi saslušanje OZN-e u: Život koji teče, str. 162 i 188.

85 Ružić, Moje uspomene, str. 40. Fra Dominik Mandić u to je doba bio član središnje uprave Franjevačkog reda u Rimu, predstavnik svih franjevačkih provincija u slavenskim zemljama i generalni gospodarstvenik (ekonom) reda. Vidi saslušanje OZN-e u: Život koji teče, str. 162.

86 Ružić, Moje uspomene, str. 42. Vidi i saslušanje OZN-e u: Život koji teče, str. 160.

87 Hitler je priznavao Sušak dijelom Italije, ali je otvorio mogućnost da i NDH ostvari svoje zahtjeve za poništenjem aneksije teritorija iz 1941. Kada je vidio da NDH ne može sama osloboditi ovaj prostor od pripadnika antifašističkog, partizanskog pokreta učinio je to njemačkim vojnim pohodom. Nakon toga, anketirani prostor od Sušaka do Bakarca nije prepustio NDH već je organizirao njemačku vojnu upravu Operationszone Adriatisches Küstenland koja je obuhvaćala prostor Furlanije, Gorice, Trsta, Istre, Rijeke i područja anektiranih 1941. 10. rujna 1941. Time je otvorio mogućnost da i Treći Reich ostvari izlazak na more pozivajući se da su ovo uglavnom povijesni prostori koji su pripadali austrijskom dijelu Austro-Ugarske monarhije. Bartulović, Sušak, str. 261-263.

88 Ružić, Moje uspomene, str. 47. 
potprefekta pokrajine. ${ }^{89}$

Ružić navodi da je postao predsjednik Građanskog odbora za pomoć siromasima, stradalnicima i povratnicima, navodeći da je ,podupirao obitelji čiji su hranitelji bili u partizanima " ${ }^{90}$ a to je bila jedna od točaka optužnice nakon rata. Treba razlikovati Privremeni građanski odbor na čelu s v.d. gradonačelnikom Kolaciom, kao neku vrstu gradskog zastupstva bez prava donošenja odluka od odbora za pomoć kojem je Ružić bio na čelu. ${ }^{91}$ Ružić je tražio dozvolu za rad od odvjetničke komore za područje Povjereničtva. Vjerojatno je u drugoj polovici 1944. od riječkog biskupa Uga Camozza i sušačkog župnika Martina Bubnja dobio 500.000 lira za koje tvrdi da su potjecale od izbjegličke vlade u Londonu. Dio je dao za selo Lipu koje su Nijemci spalili, a stanovnike uglavnom ubili 30. travnja 1944, dio župniku Bubnju, 60.000 mjesnom Narodnooslobodilačkom odboru Sušak, a ostatak je dijelio Građanski odbor za pomoć. ${ }^{92}$ Groteskno je to što je nakon rata Ružić optužen i za prikupljanje i podjelu pomoći mimo partizanskog, antifašističkog pokreta.

Iako u svojim sjećanjima to ne piše, dr. Ružića kontaktirao je Giovanni Rubinich u jesen 1944. o prijedlogu stvaranja zasebne države - Liburnijske konfederacije, koja bi imala tri kantona (Rijeka, Sušak i Slovenija). Zbog toga su ga saslušavale nove vlasti 1945. godine. Njegovo neslaganje može se ipak posvjedočiti u pismu dr. Anti Mandiću vjerojatno od 13. listopada 1944., u kojem ga obavještava o tom planu, ali zaključuje: „Ma nije vrijeme ni mjesto da se mi na Rijeci u političkoj suradnji miješamo s Talijanima. Mi imademo stare naše račune da uredimo... nu tu držim političku saradnju sa njima opasnu, jer će kako se oni spremaju morati doći do otvorene borbe s njima." "93 Ipak, Ružić shvaća specifičnost Rijeke pa izjavljuje da bi unutar Hrvatske trebala imati ,neki specijalni položaj “ kao što je to predlagao i povjerenik za vanjske poslove NKOJ-a, dr. Josip Smodlaka. ${ }^{94}$ To nije pristajanje uz autonomaštvo, već shvaćanje da prema talijanskom stanovništvu treba postupati drukčije, a isto tako i voditi predstojeću diplomatsku borbu da ovi krajevi uđu u Hrvatsku u sastavu tadašnje jugoslavenske države..$^{95}$

Ružić piše i o likvidaciji pukovnika Hinka Rescha i njegove žene koje je usmrtio ustaški „major“, nakon što su odbili krenuti u povlačenje pred partizanima 20. travnja 1945., dan prije oslobođenja Sušaka. Sakriven u drvarnici Vile Bačić, Ružić je dočekao oslobođenje Sušaka. ${ }^{96}$ Opasnosti gubitka života prijetile su sa svake strane. Nakon uspostave nove vlasti bilo je bjegunaca koji su htjeli pobjeći Saveznicima, a

89 Bartulović, Sušak, str. 262-26, a o stajalištima NDH vidi na str. 273-277.

90 Ružić, Moje uspomene, str. 47. Vidi i saslušanje OZN-e u: Život koji teče, str. 160.

91 Bartulović, Sušak, str. 262.

92 Ružić, Moje uspomene, str. 48. Vidi i saslušanje OZN-e u: Život koji teče, str. 167, 175 i obranu dr. Perčića na suđenju, str. 204.

93 Strčić i Polić, Prilog, str. 77-78. Vidi i saslušanje OZN-e u: Život koji teče, str. 163 i d.

94 Saslušanje OZN-e u: Život koji teče, str. 177.

95 Upravo to se i navodi u obrani dr. Perčića na suđenju u: Život koji teče, str. 203.

96 Ružić, Moje uspomene, str. 48. Ružić ne navodi ime ustaškog bojnika. Prema Miletiću, to je bio Ventura Baljak. Miletić, Marin, Hinko Reš, sušački Schindler, Novi list, 9. travnja 2017. http://www.novilist.hr/Komentari/Kolumne/Kolumna-Marina-Miletica/Hinko-Res-susackiSchindler?meta. Ružić netočno navodi da je oslobođenje bilo 23. travnja 1945. iako se to dogodilo 21. travnja. Bartulović, Sušak, str. 306. 
Ružić pomaže ljudima koji to čine. Spominje pomoć Marti Šrepel, kćerki kipara Ivana

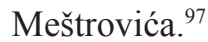

\section{DR. RUŽIĆ U PORATNOM RAZDOBLJU-SUDSKI POSTUPAK I PROGONI VLASTI}

Slijedi doba progona koje Ružić dobro procjenjuje. Svrha kaznenih postupaka pred Narodnim sudovima, osobito protiv imućnijih osoba, bila je ,konfiskacija imovine okrivljenika, a isto tako to su bili politički procesi. " protiv osoba koje nisu bile pristalice komunizma, pa makar su bili antifašisti. ${ }^{98}$ One koji izričito nisu pristali uz novu vlast treba lišiti imovine, a u političkom procesu prikazati ih i suradnicima neprijatelja ili neprijateljima naroda, sve kako ne bi mogli imati utjecaja u novom društvu.

Ružića je OZNA uhitila u srpnju 1945., uz „naivnu“ istragu za ono što, prema njegovu mišljenju, nisu bile kaznena djela. ${ }^{99} \mathrm{O}$ dostojanstvu dr. Ružića govore zapisnici saslušanja, u kojima on na više mjesta otvoreno isljedniku priznaje neslaganje $\mathrm{s}$ komunistima. Ne skriva da je 1943. poručio dr. Anti Mandiću da je na „pogrešnom putu“ “ jer on ",ne odobrava metode i sistem Komunističke Partije. "100 Dr. Smodlaki, na prijedlog ,, da stupi u pokret" odgovorio je da se na njega gleda s nepovjerenjem i da pristup ne bi bio koristan za rješavanje pitanja. ${ }^{101}$

Optužnica od 25. kolovoza 1945. dostavljena je sudu i optuženiku 27. kolovoza i sadrži sedam inkriminacija: 1. predsjedanje odborom za pomoć stradalnicima jer je dio uprave koja priznaje njemačku vlast; 2. savjetovanje dr. Špeharu i dr. Spalatinu da postanu čelnici uprave u Sušaku i Rijeci tijekom njemačke vlasti; 3. podrška stvaranju autonomne jedinice na prostoru, tzv. Liburnije; 4. slanje podataka četnicima; 5. financiranje dobrotvornog rada župnika Bubnja; 6. nagovaranje Marija Šarinića da nakon pada Italije preuzme vlast, iako postoji NOO i 7. kritika dr. Mandića jer je pristupio komunističkoj partiji. ${ }^{102}$ Prema tadašnjem receptu, prvo je napadnut u tisku, u Primorskom vjesniku 29. kolovoza 1945. ${ }^{103}$ Istog dana izveden je pred Sud za zaštitu nacionalne časti u kinu Jadran. Branitelj dr. Emanuel Perčić pobijao je navode optužnice te po točkama istaknuo: 1. da je odbor za pomoć bio dio gradske, a ne okupatorske uprave; 3. da je autonomna jedinica trebala biti unutar Jugoslavije; 4. da suradnja s četnicima nije dokazana; 5. novac dobiven iz Vatikana dan je potrebitima, pa i obiteljima članova antifašističkog pokreta, a ostatak župniku kao predstavniku crkvene vlasti; 6 . nagovaranje Šarinića da organizira vlast nakon kapitulacije Italije 1943. bila je usmjerena prema održavanju reda, a ne protiv antifašističkog pokreta i 7. prigovor dr. Mandiću bio je osobno mišljenje dano prijatelju, a ne iskaz protiv

97 Ružić, Moje uspomene, str. 48-49.

98 Ibid., str. 49.

99 Loc. cit. Zapisnici saslušanja OZN-e 19.-24. VII. 1945. u: Život koji teče, str. 159-195.

100 Saslušanje OZN-e u: Život koji teče, str. 172-173 i 184.

101 Ibid., str. 182.

102 Tekst optužnice u: Život koji teče, str. 196-199.

103 Vidi članak „Protunarodni rad i djelovanje dr. Viktora Ružića“ u: Život koji teče, str. 200-202. 
vlasti ili pokreta. ${ }^{104}$ Dr. Ružić ironično navodi da su mu sudili: listonoša, težakinja, kućna pomoćnica, učitelj i trgovac. Presuda je odbacila sve navode obrane i dr. Ružić je 29. kolovoza 1945. osuđen na deset godina gubitka nacionalne časti, dvije godine lišenja slobode i konfiskaciju imovine osim vile u kojoj živi. ${ }^{105}$ Stenografski zapisnik znakovito je izgubljen, a novi je sastavljen prema sjećanju, pa je dr. Ružić pozvan dati izjavu prema sjećanju. ${ }^{106}$ Tisak je o presudi tendenciozno pisao ${ }^{107} \mathrm{Cilj}$ je ovakve presude bio ostaviti uglednu osobu, koja nije pristala uz novu vlast bez materijalnih sredstava koje bi ga činile potencijalnim političkim protivnikom, uništiti mu ugled, onemogućiti politički rad i izlazak na izbore. Sama kazna zatvora bila je tek „privjesak" na što ukazuje njeno ukinuće već nakon dva tjedna.

Dr. Ružić 3. rujna 1945. podnosi žalbu Vrhovnom sudu i navodi da je podnio prigovor protiv optužnice jer se odnosi na djela koja su Zakonom o općoj amnestiji od 3. kolovoza 1945. amnestirana, što sud rješenjem 29. kolovoza nije uvažio. ${ }^{108}$ Sud za zaštitu nacionalne časti prestao je s radom 11. rujna $1945 .{ }^{109}$ Kazna zatvora ukinuta je rješenjem Okružnog suda za Hrvatsko primorje u Sušaku od 11. rujna 1945. temeljem Ukaza o pomilovanju od 8. rujna kojim se opraštaju vremenske kazne do dvije godine za ova djela. ${ }^{110}$

Koncem rujna dr. Ružić uložio je žalbu protiv presude i prijedlog o obnovi postupka Okružnom narodnom sudu, te iznosi: 1. da odbor nije bio pod njemačkom upravom te je pomagao i obitelji partizana; 2 . da dr. Špehara nije nagovarao da preuzme upravu, a niti nagovaranje Spalatina nije zločin jer su oni štitili ljude od progona; 3. da se o mogućoj autonomiji Trsta izjasnio i ministar Edvard Kardelj; 4. suradnja s četnicima temelji se na rukom ispravljenom strojopisu u pismu vojvode Jevđevića koji mijenja smisao teksta; 5 . da župnik Bubanj nije radio u korist ustaša te je pomagao obitelji partizana, a novac je podijeljen potrebitima o čemu postoje i zapisi; 6. Šarinića nije savjetovao da radi protiv pokreta, već da održava red i 7. kritika dr. Mandiću nije dana u korist okupatora i protivi se proklamiranim političkim slobodama. Žalbom se traži ukidanje kazne konfiskacije imovine. Priložene su izjave svjedoka i pisani dokazi. ${ }^{111}$

Vrhovni sud je 12. listopada raspravljao o žalbi te rješenjem obrazložio da

104 Završni govor obrane u: Život koji teče, str. 203-205.

105 Ružić, Moje uspomene, str. 49-50. O suđenju 1945. i ukidanju presude 1995. piše Sabljar, T., Dr. Viktor Ružić - optužbe i sudske presude u: Život koji teče, str. 153-157, tekst presude na str. 206-209.

106 Tekst primjedbi na zapisnik glavne rasprave u: Život koji teče, str. 259-260. Na str. 261-266 nastavlja se skraćeni tekst iskaza dr. Ružića na glavnoj raspravi koji je dan zbog izgubljenog stenografskog zapisnika. Tekst sadrži već spomenute navode obrane.

107 „Viktor Ružić je osudjen“, Primorski vjesnik od 31. VIII. 1945, tekst članka u: Život koji teče, str. 210-211.

108 Tekst žalbe u: Život koji teče, str. 254-258. Prigovori protiv optužnice su na str. 261-266.

109 Vidi rukom pisanu bilješku na koncu primjedbi na zapisnik s glavne rasprave u: Život koji teče, str. 260.

110 Tekst rješenja: Život koji teče, str. 228.

111 Tekst žalbe i priloga u: Život koji teče, str. 212-217. Prilozi, A-C, tj. izjave predloženih svjedoka nose datume od 21. i 22. rujna, a prilog D - novinski članak od 25. rujna pa se vrijeme podnošenja može utvrditi prema tome. 
se amnestija i pomilovanje primjenjuju samo za toč. 4. i 7. optužnice i posebnim rješenjem odlučio da Odluka o zaštiti nacionalne časti Hrvata i Srba u Hrvatskoj ne dopušta nikakav oblik žalbe, odnosno obnove postupka. ${ }^{112}$ Okružni sud je odlukom od 3. srpnja 1946. ispravio presudu od 29. kolovoza 1945. smanjujući kaznu zatvora s 24 na 18 mjeseci, ali to nije imalo učinka jer je ta kazna već ukinuta amnestijom. ${ }^{113}$ Gubitak građanske časti i konfiskacija imovine ostale su na snazi. Stoga je dr. Ružić podnio žalbu Okružnom sudu tražeći da mu se vrate časna prava kako bi obavljao odvjetničko zvanje. Sud je 22. kolovoza 1946. snizio kaznu gubitka časti, tj. gubitka političkih i pojedinih građanskih prava na sedam i pol godina dok konfiskaciju nije umanjio. ${ }^{114}$ Dr. Ružić podnosi molbu/zahtjev za zaštitu zakonitosti protiv presude od 29. kolovoza 1945. pozivajući se da je izgubljen izvorni stenogram, da je kvalifikacija djela različita u usmenoj presudi i pisanom otpravku, djela nisu kažnjiva, a kazna lišenja slobode nije bila predviđena Odlukom o zaštiti nacionalne časti. Vrhovni sud zaprimio je molbu 17. srpnja 1946. te je predsjednik ustvrdio da nema mjesta zahtjevu. ${ }^{15}$ Smatrajući da opasnost od Ružića nije više izražena, kazna gubitka političkih i nekih građanskih prava 30. lipnja 1947. smanjena je na tri godine. ${ }^{116}$

Kao karakterističan primjer postupaka nove vlasti Ružić navodi slučaj Špire Marčete, vlasnika hotela Kontinental kojeg su Talijani uhitili i internirali, njegov hotel rekvirirali, no za to su plaćali nisku naknadu, što se nastavilo i tijekom njemačke okupacije. On je osuđen za suradnju s neprijateljem, te mu je izrečena kazna konfiskacije imovine. ${ }^{117}$

Završetkom rata dovršena je jedna etapa, a komunistička struja u antifašističkom pokretu krenula je u borbu za vlast. Pritom je koristila načelo: „Tko nije s nama, taj je protiv nas!“" Protivnici su sada bili i političari građanskog usmjerenja, kao i osobe čije su životne vrijednosti bile u tom duhu, politički pluralističke, utemeljene na vjerskim pogledima, sve ono što je komunističko učenje smatralo konkurencijom. Postupak njihovog uklanjanja imao je različite oblike, od proglašavanja nazadnjacima, pa do težih ocjena - suradnika okupatora i neprijatelja naroda. Sankcije za to bile su ne samo politički progoni, nego i suđenja, oduzimanje građanske časti, što znači da je osoba gubila aktivno i pasivno pravo glasa. Konfiskacija se primjenjivala protiv imućnih pripadnika građanskog sloja, kao i bogatih seljaka koji su materijalno mogli pomoći političku oporbu. Najteže kazne bile su kazne zatvora i smrtna kazna, koje nisu bile rijetke, kao niti likvidacije bez ikakva suđenja. Nakon oslobođenja 1945. od mjesne pa do državne razine slijedi niz izbora u kojima komunisti pokušavaju dati privid političkog pluralizma. Kandidati, ali i članovi tijela vlasti su i neki pripadnici građanskog sloja, predratni politički aktivisti, pa čak i crkvene osobe okupljene u Jedinstvenu narodnooslobodilačku frontu (JNOF) ili Narodni front (NF). Ipak, nakon

112 Tekst rješenja u: Život koji teče, str. 229-231.

113 Tekst odluke u: Život koji teče, str. 227-228.

114 Tekst žalbe i rješenja u: Život koji teče, str. 218-221.

115 Tekst molbe i otpisa u: Život koji teče, str. 222-226.

116 Ružić, Moje uspomene, str. 50. Tekst žalbi na presudu, rješenja, zahtjeva za zaštitu zakonitosti, sudskog rješenja i odluke vidi u: Život koji teče, str. 212-231. Za rješenje od 30. lipnja 1947 vidi tekst na str. 248.

117 Ružić, Moje uspomene, str. 50. 
svakih izbora dio njih nije više biran i tijela vlasti su sve „čistija“, monolitnija. ${ }^{118}$

Ružić iznosi informacije o tragičnoj sudbini osoba koje su bile žrtve ,prvog naleta“. To su, npr. sušački župnik Martin Bubanj i direktor Tvornice papira Hartlieb, koji su bačeni u jamu u Kostreni. Tijelo vlasnika ljevaonice Nevia Skulla nađeno je u Rječini. Nestao je Riccardo Gigante, raniji gradonačelnik Rijeke i prefekt Riječke provincije: „Poslije rata je nestao, očito je ubijen bio. “, „, a doista nije nikome na žao učinio. “. Dr. Špehar osuđen je na prisilan rad. ${ }^{119}$ Represija se provodila i prema djeci, pa je 1946. Ružićeva kćer Nada izbačena iz gimnazije, a Vera iz prvog razreda srednje škole. „Jedini razlog zato bio je - što su bile moja djeca. “ Ipak, uz pomoć ministra školstva NRH Zlatana Sremeca one su položile školske ispite. ${ }^{120}$

Ružić zapisuje podatak da je na ispitivanju OZN-e u srpnju 1945. na upit o vezama s klerom rekao: „...sa nadbiskupom Stepincem, koji mi je slao bjegunce Srbe i Židove, da im pomognem da se sklonu ". ${ }^{21}$ Kako Ružić nema nikakve osobne koristi da 1968., kada piše svoja sjećanja, opravdava kardinala Stepinca podatku treba vjerovati, iako to $\mathrm{u}$ ispitivanju pred OZN-om ne spominje. ${ }^{122}$ Izjava govori u prilog Stepincu u sporovima o njegovoj osobi.

Ružić je prisiljen od vlasti tražiti posao kako bi uzdržavao obitelj. Javni tužitelj Vučinić predložio mu je mjesto knjižničara u Naučnoj biblioteci, gdje je doživio neugodnosti kada je nova vlast prionula na uništavanje nepoćudnih, a zapravo vrlo vrijednih talijanskih knjiga. Premješten je u Gradsko opskrbno poduzeće - GOP. No, i odatle ga je OZN-a ,otjerala“. Konačno se zaposlio u poduzeću Prehrana kao prevoditelj za talijanski jezik, a uskoro postaje i tajnik radeći do 1952. kada je otvorio odvjetnički ured. ${ }^{123}$

Nova vlast je Ružiću 1955. odbila izdati putovnicu, ali ju je dobio posredovanjem predsjednika Vrhovnog suda NRH, dr. Josipa Brnčića. Na putovanju u SAD 1958./1959. između ostalih, posjetio je dr. Vlatka Mačeka. Zapisao je Mačekovu misao koja je izražavala bojazan što bi bilo s Hrvatskom kad bi Jugoslavija u tom trenutku propala: ,... ako Jugoslavija propadne, neznam što bi od nje dobila Italija, što Austrija, što Madžarska, što Srbija - a što bi nama Hrvatima ostalo. “ Negdašnjeg ministra, Slovenca Mihu Kreka kritizirao je zbog separatizma slovenskih emigranata navodeći da je: „Uređenje Jugoslavije jedno pitanje, a njen opstanak drugo. "124

118 O pitanjima poratnih izbora na prostoru Sušaka i Rijeke vidi Bartulović, Sušak, str. 318-323.

119 Ružić, Moje uspomene, str. 4, 50-51.

120 Ibid., str. 51.

121 Ibid., str. 49.

122 Saslušanje OZN-e u: Život koji teče, str. 162, sadrži nijekanje dr. Ružića da je imao kontakte sa Stepincem, ali je kontakte u pitanju pomoći uhićenima imao s krčkim biskupom Josipom Srebreničem i senjskim biskupom Viktorom Burićem.

123 Ružić, Moje uspomene, str. 51-52.

124 Ibid., str. 53-54. Postoji podatak da se dr. Ružić tijekom 1957.-1958. susretao s bratom Gjurom Ružićem, dr. Vinkom Mikuličićem, dr. Berislavom Borčićem, Vinkom Antićem i Milanom Banićem. Milan Banić u svojim neobjavljenim sjećanjima taj skup zvučno naziva Klub predratnih političara i javnih radnika. Sjećanja Milana Banića sadrže niz važnih podataka o povijesti Rijeke, Sušaka i hrvatskoj povijesti između dva svjetska rata te bi bio značajno raditi na njihovoj obradi i objavljivanju. Autor je znatan dio podataka dobio iz preslika pisanih strojopisom s ispravcima pisanim rukopisom Milana Banića, koje je on poklonio svom nećaku 
Možda je takvo razmišljanje, na prvi pogled, čudno i projugoslavensko, ali takvo slično je napisao i dr. Ivo Pilar prije Drugog svjetskog rata, smatrajući da se Hrvatska treba polako pripremati na izlazak, radeći na svojoj izgradnji u jugoslavenskoj državi i čekajući povoljan međunarodni trenutak za osamostaljenje. ${ }^{125}$

Rehabilitacija dr. Ružića započinje 22. veljače 1995. kada su sin Gjoko v. Ruzio i unuka Matilda Ružić podnijeli Županijskom sudu u Rijeci zahtjev za ponavljanje kaznenog postupka. Rješenjem vanraspravnog vijeća od 14. lipnja dopušteno je ponavljanje kaznenog postupka. Okružno državno odvjetništvo u Rijeci je 7. srpnja odustalo od zahtjeva za kaznenim progonom, pa je sud rješenjem od 13. srpnja 1995. obustavio kazneni postupak, ukinuo presudu Suda za zaštitu nacionalne časti od 29. kolovoza 1945. kao i kasnije rješenja i odluke pravosudnih tijela. ${ }^{126}$

\section{ZAKLJUČAK}

Prigoda istraživanja izvornih rukopisa važna je za objektivno utvrđivanje povijesnih činjenica. Rukopis dr. Viktora Ružića pisan je s vremenskom distancom, koja počinje s događajima/doživljajima od 60 godina pa do 1968. Dio je zapisa osobne naravi, vjerojatno posvećen članovima obitelji na čiji je nagovor i počeo pisati. Drugi dio sadrži podatke o događajima iz hrvatske i riječke povijesti, dijelom onih u kojima je dr. Ružić sudjelovao, a dijelom njegovim ocjenama događaja i osoba. Najveći je dio zapisa provjerljiv. Ružić ne teži samoisticanju i piše objektivno. Tekst sadrži manje pogreške koje možemo pripisati uobičajenoj ljudskoj zaboravnosti, koja prekriva sjećanja.

U lepezi sjećanja istaknimo zbivanja 1918. i organiziranja narodnih vijeća Slovenaca, Hrvata i Srba. Doba nastanka Države SHS, ujedinjenje u Kraljevstvo SHS 1918. te talijanska okupacija Rijeke i Sušaka predmet su brojnih istraživanja i rasprava, a Ružić iznosi neke nepoznate detalje. Šteta je što se nije upustio u opsežniji prikaz izbora i političkog života tijekom dvadesetih i tridesetih godina 20. stoljeća, ali i kratki zapisi su važni. Dvojbe oko nekih sudova, npr. sukoba u Kerestincu i ,senjskih žrtava" predmet su budućih istraživanja. Odlaskom iz najviših državnih krugova 1939., Ružić se u sjećanjima okreće osobnom proživljavanju rata. Objektivne su prosudbe uspostave nove vlasti 1945., progona protivnika i neistomišljenika, stradanju građanskog sloja nakon 1945. Značajna su pravna vrela o sudskom postupku protiv dr. Ružića koja govore o primjeni prava bez pravde. Život dr. Ružića uči kako čovjek

gospodinu Milanu Baniću ml. i koji se od tada nalaze u njegovom posjedu. Autor se zahvaljuje Milanu Baniću ml. na njegovoj ljubaznosti.

125 Šego Marić, I., Položaj Bosne i Hercegovine u koncepcijama Ive Pilara, doktorski rad, Mostar, Pravni fakultet Sveučilišta u Mostaru, 2016, str. 216.

126 Tekst zahtjeva i rješenja u: Život koji teče, str. 232-239 i 246-248. Kao zanimljivost navedimo da se u iskazima svjedoka pri donošenju rješenja o usvajanju zahtjeva za ponavljanje kaznenog postupka (Anton Sironić, Tomislav Košćina, Ivan Šuflaj i Vladimir Dolanski) spominje akademik Lujo Margetić u iskazu Vladimira Dolanskog. On izjavljuje da je nakon kapitulacije Italije u rujnu 1943. s akademikom Margetićem obavljao „poslove policajca" oko 15 dana u opustjelom Sušaku. Šuflaj precizira da se desetak osoba okupilo da raščisti ulice i ukloni tijela poginulih. Vidi u: Život koji teče, str. 242 i 244-245. 
može sačuvati humanost, „plemstvo duha“ i u teškim vremenima osobnog stradanja.

Kritički odnos dr. Ružića spram totalitarnoga komunizma može opisati pitanje isljednika i odgovor na saslušanju u OZN-i, 21. srpnja 1945.: „,- Radi čega vi ne odobravate sistem i metode komunističke partije? - Ne odobravam već zbog razloga, zbog kojih sam u ovoj sobi. Mnijenja sam, da svaki pojedinac imade pravo na svoje slobodno političko uvjerenje, $i$ ako to ispovjeda, a da nasiljem ne ruši postojeći poredak bilo to i komunistički, nema biti pozvan na odgovornost. Držeći se tog principa, preuzeo sam i obranu komunista, jer sam bio mnijenja, da vlast nema pravo da hapsi i maltretira lice samo zato, što imaju izvjesno uvjerenje. " ${ }^{27}$

\section{LITERATURA}

1. Andrassy, Juraj, Marijan Derenčin, Ivan Ružić, Milan Rojc, Zagreb, Odvjetnik, Glasilo Advokatske komore u SRH, 9/1968, str. 174-183.

2. Bartulović, Željko, Grobnišćina 1918. - raspad Austro-Ugarske i talijanska okupacija, Rijeka, Grobnički zbornik, 9/2013, str. 61-75.

3. Bartulović, Željko, Povijest hrvatskog prava i države (kompendij za internu uporabu), Rijeka, 2008./2009.

4. Bartulović, Željko, Stečaj Banke i štedione za Primorje ("Litoralke")", Rijeka, Sveti Vid: zbornik, VII/1995, str. 71-84.

5. Bartulović, Željko, Sušak 1919.-1947, Državnopravni položaj grada, Rijeka, Pravni fakultet Sveučilišta u Rijeci, Državni arhiv u Rijeci i Adamić d.o.o., 2004.

6. Bartulović, Željko i Papić, Valter, Stjepan Radić i HPSS u riječkom "Novom listu" do 1914 i H(R)SS u Hrvatskom primorju 1920-1940., u Zborniku radova "110 godina Hrvatske seljačke stranke", Zagreb, Matica hrvatska, Povijesno društvo Križevci i Zaklada braće Radić, 2015., str. 323-346.

7. Bartulović, Željko i Ranđelović, Nebojša, Niš, Osnovi ustavne istorije jugoslovenskih naroda, Pravni fakultet Univerziteta u Nišu, 2012.

8. Bjelajac, Mile S., Generali i admirali Kraljevine Jugoslavije 1918-1941., Beograd, Institut za noviju istoriju Srbije, 2004.

9. Boban, Ljubo, Hrvatska u arhivima izbjegličke vlade 1941.-1943, Zagreb, Globus, 1985.

10. Despot, Miroslava, Pokušaj bibliografije primorskih novina i časopisa 1843.-1945., u: Rijeka, Zbornik, Matica hrvatska, Zagreb, 1953., str. 611-640.

11. Dubrović, Ervin, Viktor Ružić i jugoslavenska kraljevska vlada u Londonu, u: Život koji teče, str. 33-42.

12. Engelsfeld. Neda, Povijest hrvatske države i prava, Zagreb, Pravni fakultet u Zagrebu, 2002.

13. Giron, Antun, Zapadna Hrvatska u Drugom svjetskom ratu, Rijeka, Adamić, 2004.

14. Golenko, Dejana, Digitalna bibliografska zbirka knjiga dr. Viktora Ružića na Pravnom fakultetu Sveučilišta u Rijeci, u: Život koji teče, str. 303-315.

15. Gross, Mirjana, Erazmo Barčić, Zagreb, Odvjetnik, Glasilo Advokatske komore u SRH, 9/1968, str. 198-205.

16. Gulić, Mirjana i Lovrek, Zvonko, Dr. Viktor Ružić - ban Savske banovine (1936.-1938.), u: Život koji teče, str. 63-70.

17. Horvat, Josip, Politička povijest Hrvatske, I.-II. dio, II. izd., Zagreb, August Cesarec, 1990.

18. Janjatović, Bosiljka i Strčić, Petar, Žandarmerijski istražni spisi iz 1934. godine o članovima i simpatizerima KPJ u Hrvatskom primorju, Rijeka, Vjesnik Historijskih arhiva u Rijeci i Pazinu, XVIII/1973, str. 161-202.

127 Saslušanje OZN-e: Život koji teče, str. 188. 
19. Kolar, Mira, Dokumenti o vlasti Narodnog vijeća Države SHS nad Rijekom - listopad/ studeni 1918. g., Rijeka, Vjesnik DAR, 41-42/2000, str. 3-38.

20. Kovačić, Ivan, Branili su Hrvatsku, Rijeka, Adamić, 1997.

21. Lukežić, Irvin, Gjuro Ružić stariji i Šime Mazzura, u: Život koji teče, str. 43-61.

22. Lukežić, Irvin, Nebo nad Kvarnerom, Rijeka, Izdavački centar Rijeka, 2005.

23. Lukežić, Irvin, Tvorci modernog Sušaka, Rijeka, Sušačka revija, god. II, 5/1994, str. 1415.

24. Manojlović, Koraljka, Događaji u Senju 9. svibnja 1937., Senj, Senjski zbornik, 18/1991, str. 237-258.

25. Müller-Thomamuhl, Dagobert, Moj djed Đuro Ružić, Rijeka, Sušačka revija, god. II, 8/1994, str. 89-90.

26. Ninčević, Marjan Marino i Brčić, Filip, Diplomatski odnosi Vatikana i Kraljevine Jugoslavije: konkordat iz 1935. godine, Zagreb, Nova prisutnost, XIV/2/2016, str. 299307.

27. Perović, Ivan V., Crtice iz okupiranog Sušaka, Sušak, Primorski štamparski zavod, 1932.

28. Rački, Andrija, Povijest grada Sušaka, (reprint), Rijeka, Skupština općine Rijeka i Izdavački centar Rijeka, 1990.

29. Rošić, Đuro, O hrvatskim i riječkim advokatima u doba Provizorijuma i do anektiranja Rijeke Italiji, Zagreb, Odvjetnik, Glasilo Advokatske komore u SRH, 9/1968, str. 190197.

30. Ružić, Viktor, Moje uspomene, Rijeka, Udruga štovatelja Spomeničke knjižnice i zbirke Mažuranić-Brlić-Ružić, 2013.

31. Ružić, Viktor, Moje uspomene, preslika izvornika (u posjedu autora).

32. Strčić, Petar i Polić, Maja, Prilog poznavanju segmenata djelovanja dr. Viktora Ružića temeljem korespondencije dr. Ante Mandića, u: Život koji teče, str. 71-89.

33. Supilo, Frano, Politički spisi, ur. Šepić Dragovan, Zagreb, Znanje, 1970.

34. Šego Marić, Ivona, Položaj Bosne i Hercegovine u koncepcijama Ive Pilara, doktorski rad, Mostar, Pravni fakultet Sveučilišta u Mostaru, 2016.

35. Žic, Igor, Dr. Ivan Ružić, Rijeka, Sušačka revija, god. I, 2-3/1993, str. 29-30.

36. Život koji teče, Monografija o dr. Viktoru Ružiću (prir. Vujić, Vidoje), Rijeka, Zaklada „Dr. Viktor Ružić“ i Rotary Club Rijeka, 2018. 


\title{
Željko Bartulović*
}

\author{
Summary
}

\section{VIKTOR RUŽIĆ (1893-1976) AS PARTICIPANT IN STATE AND LEGAL PERSPECTIVE}

$\mathrm{PhD}$. Viktor Ružić was a member of distinguish Croatian family from Rijeka/ Sušak who were supporters of The Croatian Party of Rights. Fundament of research is Ružić's text My memories he wrote down in 1968 and which contributes to make picture upon his person, state and legal events he participated.

His adolescence was marked out by struggle against "hungarisation", arrival of Frano Supilo, The Rijeka Declaration in 1905 and emergence of The CroatoSerbian Coalition. He joined politics in 1918 becoming member of The National Council of Slovenians, Croats and Serbs. During Italian occupation of Rijeka and Sušak (1918-1923/1924) he was warning upon acts of Italian irredenta and problems of establishing administration of The Kingdom of SHS, particularly implementation of districts that erased collision between Croatian politicians and centralised regime in Belgrade. Notes about election in Sušak during third decade of $20^{\text {th }}$ century are important. PhD Ružić passed through his political zenith during fourth decade of century when je hold governor's position (ban) of The Banovina Savska and minister of justice in government of PhD Milan Stojadinović. After military defeat of The Kingdom of Yugoslavia 1941, during the Italian occupation/annexion Ružić has been internmented in Italy and during German military government 1943-1945 he was helping inhabitants of Sušak with group of civil politicians, but he hadn't joined anti fasict movement leaded by communists. Therefore, opponents of polyparty system and pluralism of opinion eliminated PhD Ružić from public life in a show trial 1945.

Keywords: Viktor Ružić, Sušak/Rijeka, Croatia, history of state, $20^{\text {th }}$ century.

\section{Zussamenfassung}

\section{DR. VIKTOR RUŽIĆ (1893-1976) ALS TEILNEHMER AN STAATSRECHTLICHEN EREIGNISSEN}

Dr. Viktor Ružić stammt aus einer renommierten kroatischen Familie aus Rijeka/ Sušak, welche die Kroatische Partei des Rechts befürwortete. Die Grundlage dieser Forschung stellt der im Jahr 1968 entstandene Text von Ružić Moje uspomene dar,

* Željko Bartulović, Ph. D., Full Professor, Faculty of Law, University of Rijeka; zeljko@pravri. hr. 
welcher der Entstehung des Bilds über seine Person und die politischen Ereignisse, an denen Ružić teilnahm, beiträgt.

Seine Jugend wurde durch den Kampf gegen Ungarisierung, das Ankommen von Frano Supilo, die Resolution von Rijeka 1905 und die Entstehung der KroatischSerbischen Koalition geprägt. In die Politik stieg Ružić im Jahr 1918 als Mitglied des Volksrates des Staates der Slowenen, Kroaten und Serben ein. Während der italienischen Besetzung von Rijeka und Sušak (1918-1923/1924) warnte Ružić vor den Befürwortern des Irredentismus und den Problemen bei der Gewaltherstellung des Königreichs SHS, insbesondere bei der Einführung von oblasti, was große politische Konflikte zwischen den kroatischen Politikern und dem Regime Beograds verursachte. Wichtig sind auch die Angaben über die während der 20er Jahren in Sušak durchgeführten Wahlen. Den politischen Zenit erlebte Ružić in den 30er Jahren des XX. Jahrhunderts, als er die Funktion des Banus von Savska Bannschaft und die des Justizministers in der Regierung von Dr. Milan Stojadinović erfüllte. Nach dem militärischen Zusammenbruch des Königreichs Jugoslawiens 1941 wurde Dr. Ružić während der italienischen Besetzung in Italien interniert. Zur Zeit der deutschen Militärverwaltung 1943-1945 half Ružić zusammen mit einer Gruppe der Politiker den Einwohnern, aber er trat der von Kommunisten geführten antifaschistischen Bewegung nicht bei. Nach dem Sieg des Antifaschismus 1945 schließen die Gegner des demokratischen Mehrparteiensystems und des Meinungspluralismus Dr. Ružić durch einen Schauprozess aus dem öffentlichen Leben aus.

Schlüsselwörter: Viktor Ružić, Sušak/Rijeka, Kroatien, die Geschichte des Staates, das XX. Jahrhundert.

Riassunto

\section{IL DR. VIKTOR RUŽIĆ (1893-1976) PARTECIPE DEGLI AVVENIMENTI GIURIDICO-STATALI}

Il dr. Viktor Ružić fu membro di una nota famiglia croata di Fiume/Sussak, i cui membri furono sostenitori del Partito Croato dei Diritti. Il fondamento di questa ricerca è il testo di Ružić dal titolo Moje uspomene (le mie memorie) risalente al 1968, il quale contribuisce alla creazione del ritratto della sua personalità e degli avvenimenti politici cui prese parte.

Gli anni della sua giovinezza furono caratterizzati dalla lotta contro la magiarizzazione, dall'arrivo di Frano Supilo, dalla dichiarazione di Fiume del 1905 e dall'avvento della coalizione croato-serba. Entra in politica nel 1918 con l'ingresso nel comitato popolare dei Sloveni, Croati e Serbi. Durante l'occupazione italiana di Fiume e di Sussak (1918-1923/1924) avverte circa le condotte degli irredentisti ed i problemi in occasione della creazione del governo del Regno dei Serbi, Croati e Sloveni, in particolare con riguardo all'introduzione delle competenze, il che fece 
sorgere conflitti tra i politici croati ed il regime centralizzato a Belgrado. Di rilievo sono i dati relativi alle elezioni a Sussak nel corso degli anni venti. Il dr. Ružić raggiunse l'apice politico negli anni trenta del XX secolo, quando rivestì la carica di Bano della Banovina Savska e di ministro della giustizia nel governo del dr. Milan Stojadinović. Dopo la sconfitta militare del Regno di Jugoslavia nel 1941, durante l'occupazione/annessione italiana il dr. Ružić venne internato in Italia; mentre durante l'amministrazione militare tedesca tra il 1943 ed il 1945 insieme ad un gruppo di politici aiutò la popolazione, ma non si unì al movimento antifascista guidato dai comunisti. Per questo motivo nel 1945 gli oppositori del sistema pluripartitico e del pluralismo di pensiero mediante un processo giudiziale "montato" allontanarono il dr. Ružić dalla vita pubblica.

Parole chiave: Viktor Ružić, Sussak/Fiume, Croazia, storia dello stato, XX secolo. 